Research Paper

\title{
Construing the Biochemical and Molecular Mechanism Underlying the In Vivo and In Vitro Chemotherapeutic Efficacy of Ruthenium-Baicalein Complex in Colon Cancer
}

\author{
Yixuan Wang1, Li Bian ${ }^{\bowtie}$, Tania Chakraborty ${ }^{3}$, Torsha Ghosh ${ }^{3}$, Pallakhi Chanda ${ }^{3}$, Souvik Roy ${ }^{3 凶}$ \\ 1. Department of Nephrology, China-Japan Union Hospital of Jilin University, Changchun, Jilin, 130033, China \\ 2. Department of Radiotherapy, The Second Hospital of Jilin university, Changchun, Jilin, 130041, China \\ 3. Department of Pharmaceutical Technology, NSHM Knowledge Campus- Kolkata, 124 B.L. Saha Road, Kolkata -700053, West Bengal, India
}

$\triangle$ Corresponding authors: Li Bian, Department of Radiotherapy, The Second Hospital of Jilin University, Changchun, Jilin, 130041, China. Tel \& Fax: 15526852158; Email: bianli25450@sina.com or Souvik Roy, Department of Pharmaceutical Technology, NSHM Knowledge Campus- Kolkata, 124 B.L. Saha Road, Kolkata -700053, West Bengal, India. Tel : +91 9831345318; Fax : +91 33 24033424; E-mail:souvik.roy@nshm.com, souvikroy35@gmail.com

(c) Ivyspring International Publisher. This is an open access article distributed under the terms of the Creative Commons Attribution (CC BY-NC) license (https://creativecommons.org/licenses/by-nc/4.0/). See http://ivyspring.com/terms for full terms and conditions.

Received: 2018.11.01; Accepted: 2019.03.04; Published: 2019.04.22

\begin{abstract}
In pursuit of a novel approach in colon cancer therapy, we explored the ability of ruthenium baicalein complex to eradicate colon cancer by efficiently targeting various apoptotic pathways on human colon cancer cell line and on a DMH and DSS induced murine model of colorectal cancer. In this study, we provide direct proof of the chemotherapeutic potential of the ruthenium baicalein complex by activating p-53 dependent intrinsic apoptosis and modulating the AKT/mTOR and WNT/ $\beta$ - catenin pathways. The ruthenium baicalein complex was synthesized and its characterizations were accomplished through various spectroscopic techniques followed by assessment of antioxidant potential by DPPH, FRAP, and ABTS methods. In vitro study established that the complex increased $p 53$ and caspase- 3 expressions while down regulating VEGF and mTOR expression, induced apoptosis, and DNA fragmentation in the HT-29 cells. Acute and sub-acute toxicity study was also considered and results from in vivo study revealed that complex was effective in suppressing ACF multiplicity and hyperplastic lesions and also raised the CAT, SOD, and glutathione levels. Furthermore, the complex decreased cell proliferation and increased apoptotic events in tumor cells correlated with the upregulation of $\mathrm{Bax}$ and downregulation of $\mathrm{Bc} / 2$, WNT and $\beta$ - catenin expressions. Our findings from the in vitro and in vivo study provide robust confirmation that ruthenium baicalein complex possesses a potential chemotherapeutic activity against colon cancer and is competent in reducing ACF multiplicity, hyperplastic lesions in the colon tissues of rats by inducing apoptosis.
\end{abstract}

Key words: ruthenium baicalein complex, structural characterization, in vitro study, toxicity study, colon carcinogenesis

\section{Introduction}

Colorectal cancer (CRC) is a class of malignant neoplasm emerging from the epithelial cell lining of the colon or/and rectum that has been the third most prevailing cancer worldwide and the fourth leading cause of cancer related death [1]. Rapid increase of CRC burden has been documented in developing countries of Asia, Africa, where as stabilization of occurrence of death from CRC has been observed in countries like USA, Europe and Australia [2-3]. Escalation of CRC cases in developing countries largely relies on poor lifestyle, diet, obesity, alcohol intake, smoking etc [4]. In India CRC is the $5^{\text {th }}$ most common cancer in both male and female with one of the lowest five year survival rate in the world (less than $40 \%$ ). According to the CONCORDE-2 study the five year survival rate even falls in some parts of India 
mostly due to delays in detection and inadequate treatments [5]. Conventional ways to treat colorectal cancer are surgery, radiation, chemotherapy, targeted therapy, which may improve the five year survival rate altogether, but post-operative measurements and deleterious toxicity of long term chemotherapeutics compels researchers to develop more efficient novel drugs with minimized toxicity [6].

The incompetence of the existing treatments to abolish the disease encourages us to explore the therapeutic milieu for better and effective chemotherapeutic alternatives. The therapeutic efficacy of transition metals in cancers, metabolic disorders and neurological disorders has been demonstrated numerous times [7 - 8]. The invention of cisplatin (a platinum based drug) in 1978 spearheaded a new era of cancer treatment resulting in almost half of the cancer population being treated with platinum based drugs [9]. Despite the dynamic antineoplastic activity of platinum drugs, heinous toxicity and drug resistance have chiefly limited its use in current scenario [10]. Lately ruthenium $(\mathrm{Ru})$, a non-platinum transition metal has emerged as a probable alternative to platinum in cancer chemotherapy [7- 8]. Researchers have extensively explored the inherent properties of ruthenium, like its multiple oxidation state, iron mimicking properties, ligand exchange kinetics which impart far lesser toxic effect as compared to platinum [11]. To assess the antineoplastic activity of ruthenium several studies have been carried out and two ruthenium based moiety namely NAMI-A and KP1019 are currently in clinical trials [12-14].

The association between diet and colorectal cancer has been well documented and established for over 25 years [15]. High fiber rich foods, fruit intake and low amount of red meat, fat, alcohol consumption have all been associated with lower rates of CRC in population based studies [16-17]. Dietary flavonoids are the large classes of polyphenolic compounds that have demonstrated various pharmacological activities including anti-cancer [18-20]. Baicalein (5,6,7 trihydroxyflavone), a major, active constituents of Scutellariae radix plant (also known as Chinese Huang Qin), is a well-known component of the traditional Chinese herbal remedy having antiinflammatory and antitumor activity [15, 21]. Like other flavonoids, the principal ring system of baicalein is C6-C3-C6 which helps it to chelate with metal ions and the complexation of baicalein with metals has been reported to improve radical scavenging properties of the flavonoid [22]. Studies revealed that baicalein has potent anti-tumor activity and it induces apoptosis via a mitochondrialdependent caspase activation pathway in bladder cancer cells [23]. The chemopreventive property of baicalein in breast cancer cell line has also been successfully demonstrated earlier [24]. Other studies showed baicalein induced apoptosis in HT-29 colon tumor xenograft through the AKT pathway and arrested HCT116 adenocarcinoma cell cycle at $S$ phase via activation of the caspase cascade [25-26].

In murine CRC models, Aberrant Crypt Foci or (ACF) are the earliest identifiable lesion demarcating the progression of colon cancer [27]. It has also thus far been observed that exuberant presence of proteins like Proliferating cell nuclear antigen (PCNA) and the reticence of apoptotic processes, manipulated by a charade of pathways, is often associated with the prognosis of the disease [28]. Apart from these, alterations of proteins like p53, VEGF (Vascular Endothelial Growth Factor), mTOR (Mammalian Target of Rapamycin) signaling pathway, Bax (BcL2 associated X protein) and Bcl2 (B-cell lymphoma 2) is observed to be involved in the growth and evolution of colon cancer [29-31].

1,2-dimethylhydrazine (DMH) is a broadly used chemical to induce colorectal carcinogenesis in rodents for research purposes [32]. DMH exhibits induction of colorectal tumor in rats in a dosedependent manner [33]. To synergize colitis formation Dextran sulphate sodium (DSS) is given to the rodents in drinking water alongside DMH [34]. Administration of DSS in drinking water forms most severs murine colitis resembling that of human ulcerative colitis [35].

To the best of our knowledge, the Rutheniumbaicalein complex has not been investigated previously and is a novel moiety whose biological activities have not yet been explored. In this study, we have synthesized and characterized rutheniumbaicalein complex and evaluated its antioxidant activity and DNA binding properties. The chemotherapeutic activity of this novel complex has also been investigated in human colorectal cell line HT-29 and on a well-defined model of chemically (DMH+ DSS) induced rat colon carcinoma.

\section{Materials and method}

\section{Chemical, Reagents and cell line}

All reagents used for experimental purpose were of analytical reagent grade. Extra pure methanol, Baicalein, $\mathrm{RuCl}_{3}$. $\mathrm{xH}_{2} \mathrm{O}$, DPPH (2, 2-diphenyl-2-picrylhydrazyl), ABTS (2, 2'-azinobis 3-ethylbenzothiazoline-6-sulphonic acid diammonium salt), TPTZ $(2,4$, 6-Tri(2-Pyridyl)-s-triazine), highly polymerized CTDNA (calf thymus DNA), Tris $\mathrm{HCl}, 7$, dimethylhydrazine (DMH), dextral sodium sulphate (DSS), biotinylated goat anti-rabbit IgG, streptavidin peroxi- 
dase, 3,3'- diaminobenzidine (DAB), proteinase $K$, foetal bovine serum (FBS), insulin L-glutamine, sodium pyruvate, streptomycin, penicillin, MTT (3(4,5-dimethyl thiazole-2-yl)-2,5-diphenyltetrazoliumbromide), Annexin $\mathrm{V}$ and propidium iodide (PI) were purchased from Sigma Aldrich Chemical Co (St, Louis, Mo, USA). Rabbit anti-rat p53, Bax, Bcl2, PCNA, VEGF, caspase-3, mTOR, WNT, Beta catenin were purchased from ANASPEC Inc. (San Jose, CA, USA). The HT-29 colorectal cancer cell line was procured from National Centre Cell Science (NCCS), Pune, India. Apoptosis detection kit obtained from Takara Bio Inc (Japan). Other reagents used for the experimental purpose were obtained in the purest form from local firms.

\section{Synthesis of ruthenium-baicalein complex}

In a beaker, $900 \mathrm{mg}(3.33 \mathrm{mM})$ of baicalein was dissolved in $50 \mathrm{ml}$ of methanol with continuous stirring and a solution of ruthenium-chloride $345 \mathrm{mg}$ $(1.6 \mathrm{mM})$ was added drop wise in a molar ratio of 1:2. The solution was stirred continuously for 24 hours and $\mathrm{pH}$ was adjusted to 7 with $1(\mathrm{M}) \mathrm{NaOH}$. A dark green solid soluble in methanol and dimethyl sulphoxide (DMSO) precipitated after a few days and was stored in a vacuum desiccator over silica gel $\left(\mathrm{SiO}_{2}\right)$.

\section{Instrumental analysis}

\section{Characterization of ruthenium-baicalein complex}

UV-Visible spectra of free baicalein and ruthenium-baicalein complex $\left(1 \times 10^{-3} \mathrm{~mol} \mathrm{l}^{-1}\right)$ in $\mathrm{MeOH}$ were obtained by UV-1800 Shimadzu double beam spectrophotometer using standard $1.00 \mathrm{~cm}$ quartz cell. The formation of complex was further confirmed by Infrared spectra using FT-IR spectroscopy (ALPHA-T, Bruker, and Rheinstetten, Germany) at a range of $500-4000 \mathrm{~cm}^{-1}$. The structural elucidation of ruthenium-baicalein complex was done by the help of mass spectrometry (ESI-MS) technique. Molecular ions scanning range $(\mathrm{m} / \mathrm{z})$ were taken at 150-1100. The ${ }^{1} \mathrm{H}-\mathrm{NMR}$ spectra was performed in DMSO using Bruker- Avance- $600 \mathrm{MHz}$ spectrometer. The morphological characteristic of the sample was investigated using a scanning electron microscope (JEOL MAKE, (UK) MODEL- JSM6360) at an accelerating voltage of $17 \mathrm{kV}$. Micrographs were recorded at different magnification. X-ray diffraction of the ruthenium baicalein complex was recorded in $X^{\prime}$ Pert Pro XRD system (PANanlytical) using $X^{\prime}$ celerator operating at $40 \mathrm{kV}$ and $30 \mathrm{~mA}$ with Bragg-Brentano geometry to study the surface and morphological characteristics with step size $0.05(2 \theta)$, step time $75 \mathrm{sec}$ from 5 to 95 .

\section{Measurement of antioxidant activity of ruthenium baicalein complex}

\section{DPPH assay}

DPPH free radical scavenging capacity of the complex, ruthenium and baicalein were investigated and compared using a previously reported method by Dolatabadi [36]. Different concentrations of the complex, ruthenium and free baicalein were added to the freshly prepared solution of DPPH and their absorbance recorded at $517 \mathrm{~nm}$. The absorbance was measured for 25 minutes at every 5 minute interval $\left(A_{s}\right)$. A solution of DPPH served as blank $\left(A_{c}\right)$. The following equation has been used for the calculation of the percentage of radical scavenging activity (RSA $\%)$.

$$
(\operatorname{RSA} \%)=100\left(\mathrm{~A}_{\mathrm{C}-\mathrm{A}_{\mathrm{S}}}\right) / \mathrm{A}_{\mathrm{C}} .
$$

\section{FRAP assay}

To investigate the ferric reducing property of complex compared to baicalein the method of Benzie was followed [37]. The experiment was carried out for different concentrations $(5,10,20,30,40,50 \mu \mathrm{M})$ of the complex as well as free baicalein and ruthenium, then absorbance was observed at $593 \mathrm{~nm}$.

\section{ABTS assay}

ABTS radical scavenging activity of the ruthenium baicalein complex was carried out as per the method of Pennycooke, Cox \& Stushnoff [38]. The absorbance was monitored at $734 \mathrm{~nm}$ for $10-12$ minutes after the addition of different concentrations of baicalein and the complex into the ABTS solution (incubated 10 minutes at room temperature). The percentage of radical scavenging activity (RSA \%) was calculated by the following equation :

Radical Scavenging activity at 750nm $(\%)=1-\mathrm{A}_{\mathrm{f}}$ $/ \mathrm{A}_{0} \times 100$.

Where, $\mathrm{A}_{0}=$ Absorbance of uninhibited radical cation, $\mathrm{A}_{\mathrm{f}}=$ Absorbance measured 10-min after addition of the complex.

\section{DNA binding study of ruthenium-baicalein complex}

The mode of intercalation of calf thymus DNA by ruthenium baicalein complex was measured by UV-Visible spectra using UV-1800 shimadzu double beam spectrophotometer. Solution of the CT-DNA \& ruthenium baicalein complex was scanned using a 0.5 $\mathrm{cm}(1 \mathrm{ml})$ quartz cell. Spectra were recorded by the progressive addition of pure DNA to the ruthenium-baicalein complex [39].The stock solution of DNA (of concentration $1 \times 10^{-3} \mathrm{M}$ per nucleotide) was prepared at $\mathrm{pH} 7$ by dissolving DNA in $5 \mathrm{mM}$ 
Tris- $\mathrm{HCl}$ buffer and $50 \mathrm{mM} \mathrm{NaCl}$. A solution of CT-DNA gave a ratio of about 1.8-1.9:1 at 260-280 nm wavelength, which indicated that the DNA was free of protein. Broad absorption bands in a range of 220-370 $\mathrm{nm}$ were observed in the absorption spectra of the complex. Interaction of DNA with the complex was observed under UV-Visible spectra, the absorbance was recorded after each successive addition of DNA to a $5 \mu \mathrm{M}$ stock solution of the complex. The intrinsic binding constant was calculated from the data with the help of the following equation:

$$
\mathrm{DNA} / \varepsilon_{\mathrm{a}}-\varepsilon_{\mathrm{f}}=\mathrm{DNA} / \varepsilon_{\mathrm{b}}-\varepsilon_{\mathrm{f}}+1 / \mathrm{K}_{\mathrm{b}}\left(\varepsilon_{\mathrm{b}}-\varepsilon_{\mathrm{f}}\right)
$$

Where, DNA is the concentration of DNA in base pairs, $\varepsilon_{a}$ is the observed extinction coefficient $A_{o b s} /$ $\mathrm{Ru}, \varepsilon_{\mathrm{f}}$ corresponds to the extinction coefficient of the free compound, $\varepsilon_{b}$ corresponds to the extinction coefficient of the bound compound. $\varepsilon_{\mathrm{f}}$ is calculated from the calibration curve of the baicalein-ruthenium complex isolated in the aqueous solution. From Beer's law the $\varepsilon_{a}$ is obtained as the ratio of the measured absorbance and the ruthenium baicalein complex concentration [37].

\section{In-vitro experiments}

\section{Cell culture}

The HT-29 cancer cell line was purchased from 'National Centre for Cell Science' (NCCS), Pune. The cell line was maintained in DMEM growth media supplemented with 10\% FBS (foetal bovine serum) containing antibiotics, penicillin/streptomycin $(0.5$ $\left.\mathrm{mL}^{-1}\right)$ in an atmosphere of $5 \% \mathrm{CO}_{2} \& 95 \%$ air at $37^{\circ} \mathrm{C}$.

\section{Cell viability assay}

The assay was determined by metabolizing yellow tetrazolium salts MTT (3-(4, 5 dimethylthiozol2-yl)-2, 5- diphenyltetrazolium bromide) into reduced formazan crystals by mitochondrial succinate dehydrogenase [40]. Cells were plated in 96 well plate with $5.0 \times 10^{3}$ cells per well in culture medium and incubated overnight at $37^{\circ} \mathrm{C}$ in a $5 \% \mathrm{CO}_{2}$ humidified incubator for 24 hours and were treated with three different concentrations $(5,15,30 \mu \mathrm{M})$ of ruthenium baicalein complex for 12, 24, 36 and 48 hours in a complete growth medium. The medium was removed after treatment and MTT solution $\left(0.5 \mathrm{mg} / \mathrm{ml}^{-1}\right)$ was added to each well and incubated at $37^{\circ} \mathrm{C}$ for $3 \mathrm{hrs}$. The optical density of solubilized crystals in DMSO was measured at $560 \mathrm{~nm}$ on a microplate reader. The percentage of cell viability was calculated using the following equation.

$$
\% \text { viability }=100-\% \text { of cytotoxicity }
$$

\section{Cell cycle and detection of apoptosis by flowcytometry}

To determine the cell cycle phase distribution, HT-29 cells were brought into suspension, and a double labelling system of both FITC conjugated Annexin-V and PI medium with complex treated (at 5, 15 and $30 \mu \mathrm{M}$ concentrations) and untreated cultured HT-29 cells $(1 \times 106)$ were observed after 36 hours. Cell cycle phase distribution of nuclear DNA was performed on FACS (fluorescence-activated cell sorter), using Modfit software, a total of 10,000 events were acquired and flowcytometric data analysis was performed and a histogram of DNA content versus counts was displayed according to the method developed by Li [41].

\section{Detection of p53, mTOR, AKT, caspase-3 and VEGF and protein expression by western blotting}

The expressions of p53, mTOR, AKT, caspase- 3 and VEGF were detected in HT-29 cells by western blot analysis. The cells were treated with rutheniumbaicalein complex of doses 5, 15 and $30 \mu \mathrm{M}$ for $24 \mathrm{hrs}$ and cultured for $6 \mathrm{hrs}$ following a change in the medium. Total cell lysates at approximately $2 \times 10^{6}$ $1 \times 10^{7}$ cells per $\mathrm{ml}$ were prepared and equivalent amounts of proteins were resolved by SDS-PAGE electrophoresis (10-12\%) followed by transfer to PVDF (polyvinylidene difluoride) membranes and blocked with Tris buffer $(25 \mathrm{mM})$ containing $0.15 \mathrm{M} \mathrm{NaCl}, 0.1$ $\%$ Tween 20 and 2-5\% non-fat dry milk. The membranes were incubated with p53, caspase-3, VEGF, mTOR primary antibodies at $4^{\circ} \mathrm{C}$ followed by horseradish peroxidase-labelled secondary antibody for $1 \mathrm{hr}$. The membrane was again washed for 30-60 minutes with 5 or more changes in blotting buffer. Chemiluminescent (ECL Western Blotting) kit was used to detect the protein loading against $\beta$-actin as control [42].

\section{In-vivo study}

\section{Animal husbandry and maintenance}

Swiss albino mice (25-35 gm) of both sexes was selected for toxicity study, and for in-vivo carcinogenic study, 3-4 week old male Sprague-Dawley rats (80-100 grams) were purchased from Indian Institute of Chemical Biology (IICB), Kolkata, India and quarantined for a week. Animals were kept in polypropylene cages maintained on a 12-hour light/dark cycle, at RT of $22^{\circ} \mathrm{C}\left( \pm 3^{\circ} \mathrm{C}\right)$ and humidity at roughly $50-58 \%$. All rats were maintained on a semi purified basal diet (Lipton, Calcutta, India) (Table 1) and demineralized water ad libitum for 10 days before the experiment. 
Table 1. Composition of food mixture.

\begin{tabular}{ll}
\hline Ingredient & Amount $(\mathrm{g} / \mathbf{k g}$ diet $)$ \\
\hline Wheat flour (Triticum aestivum) $^{\mathrm{a}}$ & 500 \\
Bengal gram (Cicer artetinum) $_{\text {Maize dust (Zea mays) }}$ & 150 \\
Milk powder (Spray dried) & 150 \\
Macromineral mix & 150 \\
Micromineral mixc & 49.75 \\
\hline
\end{tabular}

\section{Toxicity study}

\section{Acute oral toxicity study (LD50)}

The acute toxicity study of ruthenium-baicalein complex was conducted by following Guidelines of the Organization for Economic Co-operation \& Development (OECD) was maintained for testing of chemicals, TG 420 (adopted December 2001) to obtain the $\mathrm{LD}_{50}$ value and to determine the safe doses of the complex. Thirty Swiss albino mice (both sexes) (nulliparous \& non pregnant; $30 \pm 5 \mathrm{gm}$ ) were taken and randomized into five groups (six animals per group, three of each sex) namely control (given $0.5 \%$ carboxy methyl cellulose prepared in double distilled water as a vehicle at a dose volume of $10 \mathrm{ml} / \mathrm{kg}$ body weight) and test $(1000,800,600,300 \mathrm{mg} / \mathrm{kg}$ of the ruthenium baicalein complex) group. Immediately after drug administration, the animals were provided with food and water and kept under observation for three days [43].

\section{Sub-acute toxicity studies}

Healthy adult male \& female Swiss albino mice ( $30 \pm 5 \mathrm{gm})$ were randomly allotted to four experimental groups: complex treated $(50,100,200,400$ $\mathrm{mg} / \mathrm{kg}$ ) and $0.5 \%$ carboxy methyl cellulose (CMC) served as a control group. Each group consisted of 10 mice, 5 of each sex. The animals were treated with ruthenium-baicalein complex orally and sacrificed after 28 days by ether anesthesia for further hematological, serum biochemical and histopathological studies.

\section{Hematological and serum biochemical study}

Blood samples were collected into EDTA tubes (Merck Pvt. Ltd Mumbai, India) for the assessment of hematological parameters including Red blood cell (RBC) count, Haemoglobin (HB) concentration, Mean Corpuscular Haemoglobin (MCH), Mean Corpuscular Volume (MCV), Mean Corpuscular Haemoglobin Concentration (MCHC), platelet (PLT) count, white blood cell(WBC) count and WBC differential counts (lymphocyte, monocyte, basophil, eosinophil) and were examined by Medonic CA-620 cell analyzer system (Boule Medical, Stockholm Sweden).Serum Biochemistry parameters like alanine aminotransferase (ALT), aspartate aminotransferase (AST), alkaline phosphatase (ALP), Glucose (GLU), creatinine, blood urea nitrogen (BUN), total bilirubin (TP) and Cholesterol were analyzed using a Microlab 3000 auto analyzer (Merck Pvt. Ltd. Mumbai, India).

\section{Histopathological study of mice organs}

After 28 days sub-acute toxicity study, major organs like liver, kidney, stomach and testis were collected from each group and preserved in 10\% formalin solution. Tissues were dehydrated through graded alcohol and embedded in low melting point paraffin wax on a glass slide of $5 \mu \mathrm{m}$ thickness. The sections were deparaffinized in Xylene \& rehydrated through graded alcohol and stained with hematoxylin and eosin (H\&E) for microscopic evaluation.

\section{In-vivo experiments}

\section{Experimental Protocol}

The animals were divided into six groups assigned as I, II, III, IV, V, VI, VII and each group consisted of six animals. After 10days acclimatization, DHM at a dose of $30 \mathrm{mg} / \mathrm{kg}$ body weight was administered by a single intraperitoneal injection to the animals of group II to VII. On the seventh day $2 \%$ DSS was given in drinking water and continued for a week [18]. The experimental design of the groups is given below

- Group I: the normal control group.

- Group II: comprised of carcinogen (DMH+DSS) treated animals.

- Group III: carcinogen (DMH+DSS) treated animals supplemented with $50 \mathrm{mg} / \mathrm{kg}$ body weight dose of the complex.

- Group IV: carcinogen (DMH+DSS) treated animals supplemented with $100 \mathrm{mg} / \mathrm{kg}$ body weight dose of the complex.

- Group V: carcinogen (DMH+DSS) treated animals supplemented with $200 \mathrm{mg} / \mathrm{kg}$ body weight dose of the complex.

- Group VI: carcinogen (DMH+DSS) treated animals supplemented with $100 \mathrm{mg} / \mathrm{kg}$ body weight dose of ruthenium.

- Group V: carcinogen (DMH+DSS) treated animals supplemented with $100 \mathrm{mg} / \mathrm{kg}$ body weight dose of baicalein.

After 20 weeks, the animals were sacrificed under ether anesthesia followed by further studies.

\section{ACF counts of colon}

The presence of ACF on the colonic mucosal layer was identified from the normal crypts by their dark stain, elliptical shape and thick epithelial lining. The entire colon was observed for adenocarcinoma. 
The total number of ACF present in each animal colon was noted. The distal colon tissue $\left(5 \mathrm{~cm}^{2}\right)$ was cut open and fixed flat on filter paper and fixed with $10 \%$ buffered formalin for $12 \mathrm{~h}$ and then stained with $0.1 \%$ of methylene blue in PBS for $5 \mathrm{~min}$. Specimens were observed under microscope (40X magnification). ACFs were clearly identified, counted and calculated as Number of counts $/ 5 \mathrm{~cm}^{2}$ [44].

\section{Histopathological evaluation of colon}

Ten animals from each group were randomly selected and the distal colon tissue was excised from ether anesthetized rats. The tissue was fixed in $10 \%$ formalin routinely processed and cut in $5 \mu \mathrm{m}$ thickness before placing on the slides. The sections were stained with hematoxylin and eosin (H\&E).

\section{Antioxidant activity of homogenized colon tissues}

For the estimation of enzymatic antioxidants, tissue were crushed and homogenized $(10 \% \mathrm{w} / \mathrm{v})$ in $0.1 \mathrm{M}$ phosphate buffer ( $\mathrm{pH} 7.0$ ) and centrifuged for $10 \mathrm{~min}$ and the resulting supernatant was used for enzyme assays [45].

\section{Estimation of catalase activity}

Catalase activity was performed by the process described by Sinha and his co-workers [46]. The absorbance was recorded at $620 \mathrm{~nm}$; CAT activity was expressed as $\mu \mathrm{Mol}$ of $\mathrm{H}_{2} \mathrm{O}_{2}$ consumed $/ \mathrm{min} / \mathrm{mg}$ protein.

\section{Estimation of Superoxide dismutase (SOD) activity}

The activity of superoxide dismutase was assayed by the method of Awasthi [47]. This activity was expressed as units $/ \mathrm{min} / \mathrm{mg}$ protein.

\section{Estimation of Glutathione peroxidase (GPx) Activity}

GPx activity was measured by the method described by Rotruck [48]. The activity was expressed as $\mu \mathrm{Mol}$ of GSH consumed/min/mg protein.

\section{Immunohistochemical determination of colon tissue}

The formalin fixed, paraffin embedded tissues were cut into $5 \mu \mathrm{m}$ thick to mount in the glass slides and deparaffinized followed by immersion in $\mathrm{H}_{2} \mathrm{O}_{2}$. The sections were incubated with goat serum for 1hour followed by treatment with anti-mouse WNT, $\beta$-catenin, Bcl2 and Bax antibodies (at a ratio of 1:200) and incubated at $4^{\circ} \mathrm{C}$ overnight. The slides were washed with PBS and treated with biotinylated secondary antibody streptavidin biotin horseradish peroxidase complex and incubated for $30 \mathrm{~min}$. The sections were developed using $\mathrm{DAB}$ and were counterstained with hematoxylin. The labeling index was calculated as percentage of Wnt, Beta catenin, Bcl2, Bax positive cells per total number of cells counted.

\section{Cell proliferating assay}

The formalin fixed, paraffin embedded tissue section were cut into $5 \mu \mathrm{m}$ thick to mount in the glass slides coated with Poly-L-lysine. Briefly deparaffinzed and rehydrated tissues were immersed in $\mathrm{H}_{2} \mathrm{O}_{2}$ (3\% in methanol) followed by incubation with the goat serum for 1 hour. After washing the tissue in PBS, they were incubated with anti-mouse PCNA antibody at $4^{\circ} \mathrm{C}$ overnight. The positive control slides were treated with streptavidin biotin horseradish peroxidase complex at room temperature for $30 \mathrm{~min}$. Tissues were developed with DAB (3,3'- diaminobenzidine) as chromogen and counter stained with hematoxylin [49].

\section{Apoptotic assay by TUNEL method}

The formalin fixed, paraffin embedded and poly-L-lysine coated tissues were treated with proteinase $\mathrm{K}(20 \mu \mathrm{g} / \mathrm{ml}$ in PBS) for 15 mins at room temperature for the digestion of non-specific proteins and rinsed with double distilled water. The tissues were then quenched with $\mathrm{H}_{2} \mathrm{O}_{2}$ (2\% in PBS) for $5 \mathrm{~min}$ at room temperature followed by incubation with terminal deoxynucleotidyl transferase (TdT) buffer (30mM Trizma base, $\mathrm{pH}$ 7.2, $140 \mathrm{mM}$ sodium cacodylate, $1 \mathrm{mM}$ cobalt chloride) followed by $\mathrm{TdT}$ reaction solution containing TdT and dUTP for $90 \mathrm{~min}$ at $37^{\circ} \mathrm{C}$, then $2 \%$ standard saline citrate was applied to the tissues $(10 \mathrm{~min})$ for washing at room temperature to stop the reaction. The tissue sections were incubated for 30 mins at RT with anti-digoxigenin peroxidase after washing with PBS. Tissues were developed with $\mathrm{DAB}$ (3, 3'diaminobenzidine) as chromogen and counter stained with hematoxylin. Sections were then washed, dehydrated and mounted. Apoptotic cells were identified by a brown stain over the nuclei [49].

\section{Determination of labeling and apoptotic index}

The labeling index (LI) was calculated as the \% PCNA-positive nuclei / total number of cells counted. The apoptotic index (AI) was calculated as the \% TUNEL- positive cells/ total number of cells counted.

\section{Statistical Analysis}

The result was designated as mean \pm standard error mean (SEM).Statistical comparison were carried out by t-test and one way analysis of variance (ANOVA) by using Graph pad prism software followed by post hoc test (Dunnet's $t$ test), difference 
were considered to be statically significant when $\mathrm{P}<0.05$.

\section{Results}

\section{Instrumental analysis}

In the absorption spectrum of baicalein, two prominent characteristic absorption peaks were identified at 340 and $223 \mathrm{~nm}$ for band I and band II (Figure 1Aa) respectively. After the addition of methanolic solution of ruthenium chloride the change in spectrum can be easily observed as band I shifts to $367 \mathrm{~nm}$ (band III) and band II is displaced from 223 $\mathrm{nm}$ to 253 (band IV) in Fig 1 B. The spectra observed at $253 \mathrm{~nm}$ representing band IV is characteristic for the formation of the complex. The spectroscopic analysis of the interaction between baicalein and ruthenium was carried out using Job's method of continuous variation. It was observed that the intensity of the absorption at $367 \mathrm{~nm}$ is a function of both baicalein and ruthenium. From the graph (Figure 1C), it was found that at $\mathrm{pH} 7.4$, the ligand chelates with ruthenium at ratio of 1:2 with a maximum absorbance at 0.65 . The FTIR spectra of the complex and baicalein were recorded in order to determine the coordination sites and binding properties of baicalein with ruthenium which are depicted in the figure 1D and the data are analysed in the table 2 . The shifting of the band frequencies suggests the interaction of the ligands and the metal atom. The $\mathrm{v}(\mathrm{M}-\mathrm{O})$ band observed at $574.37 \mathrm{~cm}^{-1}$ in the IR spectra of the complex confirms the formation of complex which was not accessible in the IR spectrum of baicalein. The chemical shift in the ${ }^{1} \mathrm{H}$ NMR spectra of both the complex and the free baicalein has been illustrated in the table 3. The NMR spectra of the complex reveal the absence of $5-\mathrm{OH}$ proton, indicating that ruthenium removes one proton from the flavonoid baicalein upon complexation. This information confirms that the chelation took place through the $5-\mathrm{OH}$ and 4-CO groups of the baicalein. (Figure 1F). Figure $1 \mathrm{E}$ depicts the mass spectrum and fragmentation mechanism of the ruthenium-baicalein complex. The molecular ion peak with $\mathrm{m} / \mathrm{z} 710.44$ due the addition of two baicalein and one ruthenium and two chlorine molecule is suggestive of the formation of a new complex. The mechanism of fragmentation of the complex has been depicted in figure 1E. Scanning electron microscopy was carried out at 100X ,500X and 700X [Figure 1(I), (H) and (G)] magnifications and the complex appeared as small clumps with asymmetrical surface. The X-ray diffraction study demonstrates the various typical anticipation of the complex in which sharp peaks appeared due to its distinctive crystalline structure at various diffraction angles [Figure 1J].
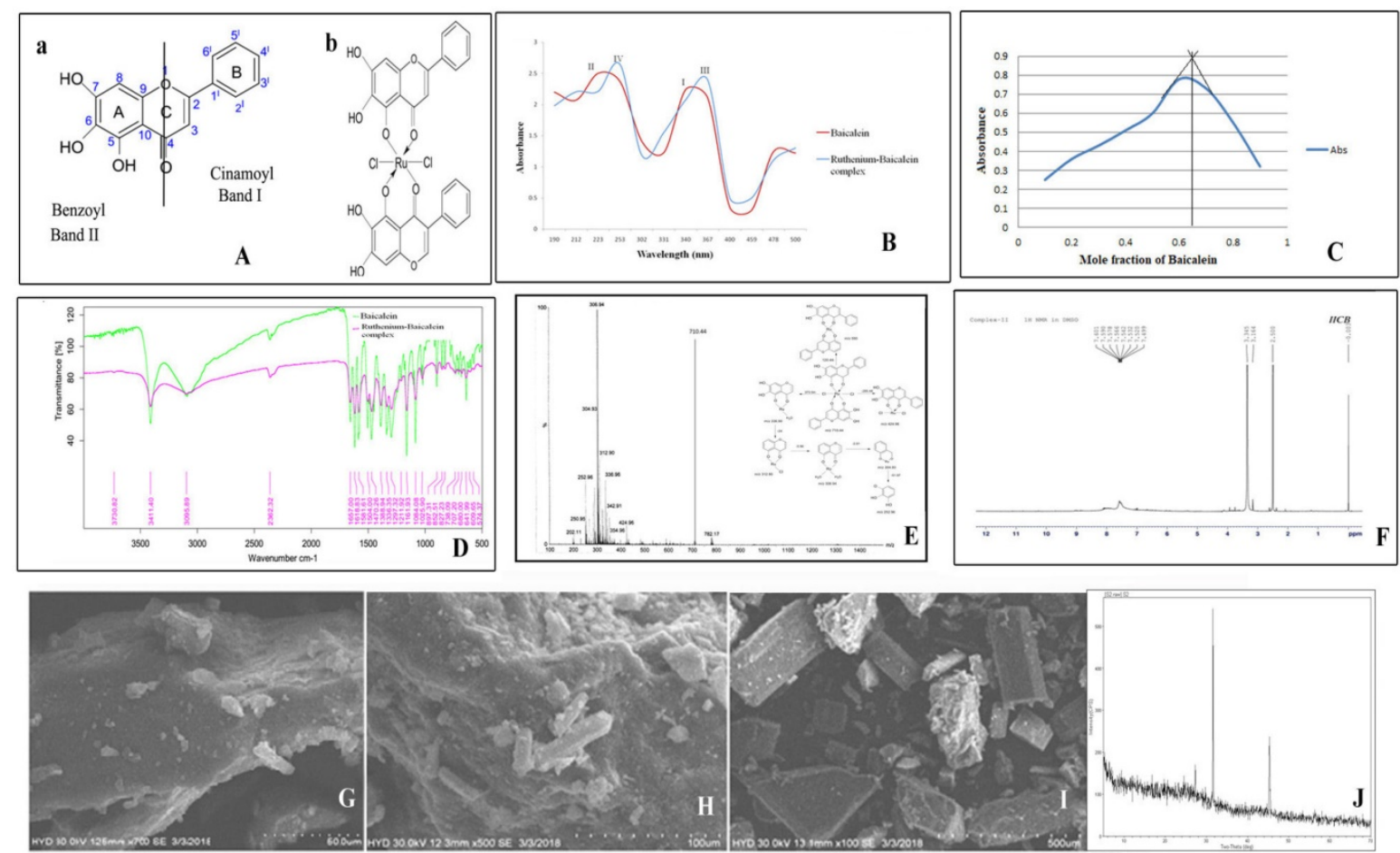

Figure 1. (A) Structure of the flavonoid and the complex (a) Basic structure of the flavonoid baicalein (b) Structure of the ruthenium baicalein complex. (B) UV-Visible spectra of baicalein and ruthenium- baicalein complex. (C) Plot of absorbance vs mole fraction of baicalein at $367 \mathrm{~nm}$. (Continuous Variation Method). (D) FTIR spectra of baicalein and ruthenium baicalein complex.(E) Mass spectroscopy of ruthenium baicalein complex showing the molecular ion peaks and the fragmentation mechanism of the complex. (F) $1 \mathrm{H}$ NMR spectra of ruthenium baicalein complex. Scanning electron microscopy (SEM) of the complex at (G) $400 X$, (H) $250 \mathrm{X}$ and (I) $50 \mathrm{X}$. (J) X-ray diffract grams of ruthenium baicalein complex. 
Table 2. FTIR spectrum of Baicalein and Baicalein Ruthenium Complex (band position

\begin{tabular}{lllllll} 
Compound & $\mathbf{v}(\mathbf{H}-\mathrm{O})$ & $\mathbf{v}(\mathbf{C}=\mathbf{O})$ & $\mathbf{v}(\mathbf{C}=\mathrm{C})$ & $\mathbf{v}(\mathbf{C}-\mathrm{OH})$ & $\mathbf{v}(\mathrm{C}-\mathrm{O}-\mathrm{C})$ & $\mathbf{v}(\mathbf{M}-\mathrm{O})$ \\
\hline Baicalein & 3411.40 & 1657.91 & 1213.08 & 1024.63 & 1161.64 & --- \\
$\begin{array}{l}\text { Ruthenium- } \\
\text { Baicalein }\end{array}$ & 3434.57 & 1634.83 & 1245.24 & 1025.29 & 1174.20 & 574.37 \\
& & & & & &
\end{tabular}

Table 3. Chemical shift $(\delta, \mathrm{ppm})$ of Baicalein and Baicalein -Ruthenium Complex

\begin{tabular}{lllllc}
\hline & $\mathbf{6 - O H}$ & $\mathbf{7 - O H}$ & $\mathbf{5 - O H}$ & $\mathbf{8 - H}$ & $\mathbf{3}^{\prime} \mathbf{4}^{\prime} \mathbf{\prime}^{\prime} \mathbf{5}^{\prime} \mathbf{- H}$ \\
\hline Baicalein & 12.48 & 10.77 & 13.06 & 6.64 & 7.59 \\
Ruthenium Baicalein & 12.48 & 10.82 & ----- & 6.63 & 7.59 \\
\hline
\end{tabular}

\section{Measurement of anti-oxidant status of Ruthenium baicalein complex}

The DPPH absorption patterns of baicalein, ruthenium and ruthenium baicalein complex at various concentrations were measured at $515 \mathrm{~nm}$ are illustrated in Figure 2 (A). With an increasing amount of time the complex showed higher DPPH absorption than its parent molecules. Figure 2 (A) illustrates that the RSA (Radical Scavenging Activity) of parent molecule is about $60.82 \%$ and that of the complex is $74.23 \%$. The complex, thus presented better inhibitory effect in the DPPH absorption patterns compared to the ligand which can be attributed to the introduction of the radical-sensitive $\mathrm{Ru}-\mathrm{O}$ bond in the complex.

The absorbance of baicalein and rutheniumbaicalein complex in the presence of $\mathrm{Fe}^{+3}-\mathrm{TPTZ}$ was measured at $593 \mathrm{~nm}$ by absorbance variation during 10 min of interaction of the subjected compound with FRAP reagent. The decrease in absorbance is proportional to the antioxidant content [39]. Figure 2 (C) confirms the increase in the antioxidant potential of the complex as compared to free baicalein. These findings propose that baicalein and ruthenium baicalein complex are capable of donating protons and could therefore terminate a chain reaction. Thus, it can be concluded that metal chelation increases the electron transfer from baicalein and thereby increases the redox potential of ruthenium-baicalein complex.

Figure 2 (B), demonstrates the ABTS radical scavenging activity of baicalein and rutheniumbaicalein complex. Absorption of active ABTS solution at $734 \mathrm{~nm}$ was found to decrease significantly in presence of different concentrations of the complex. The ABTS radical scavenging activity of the complex was found to be more than the free baicalein which can be attributed to the molecular structure of the flavonoid. The higher antioxidant activity thus may be due to the presence hydroxyl groups, and their hydrogen atoms donating ability that has been increased following chelation with ruthenium.


(B)
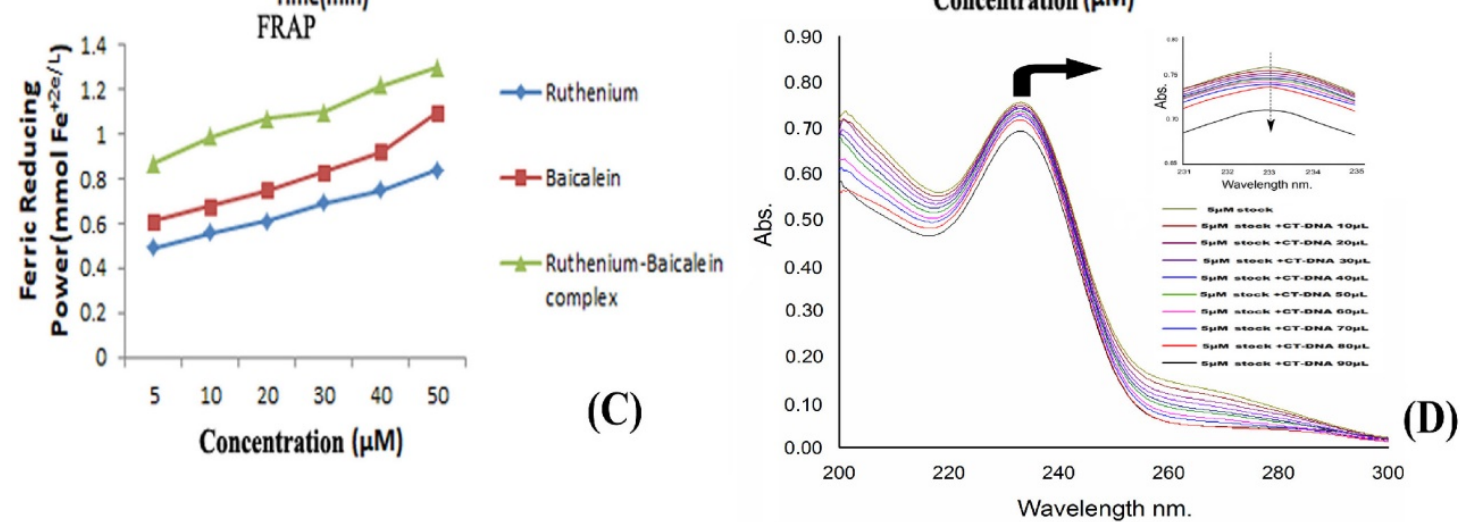

Figure 2. Measurement of anti-oxidant activity of the complex. (A) Anti-oxidant activity of ruthenium baicalein complex by DPPH method. (B) Anti-oxidant activity of the ruthenium baicalein complex by ABTS method. (C) Anti-oxidant activity of ruthenium baicalein complex by FRAP method. (D) Absorbance spectra of CT-DNA in the presence of ruthenium baicalein complex. (E) Effect of ruthenium baicalein complex on in-vivo antioxidant enzymes SOD (superoxide dismutase), CAT (catalase) and (glutathione) GST. * $\mathrm{p}<0.05$ as compared to the carcinogen control, \# $\mathrm{p}<0.01$ as compared to the carcinogen control. 


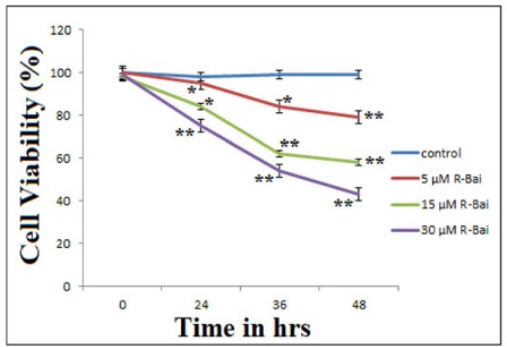

(A)

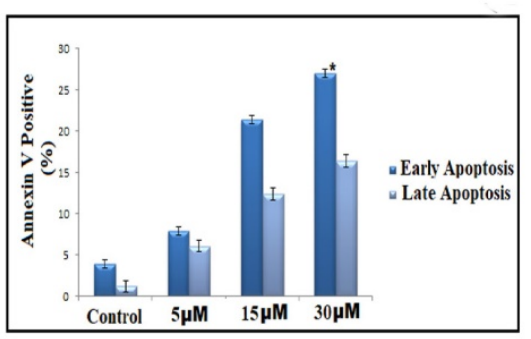

(D)

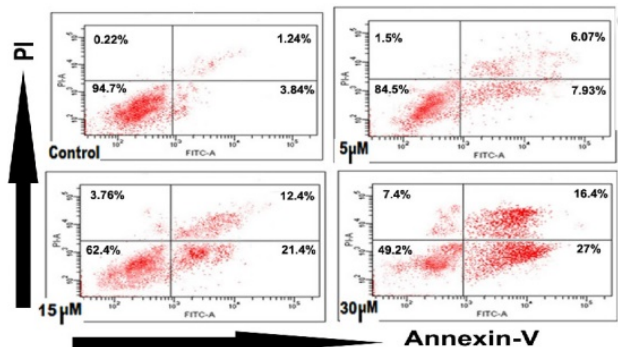

(B)

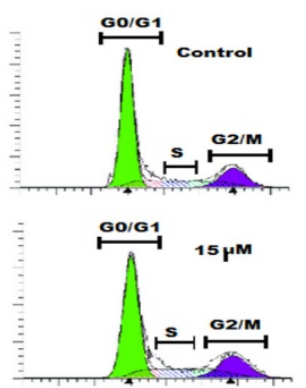

(E)


(C)

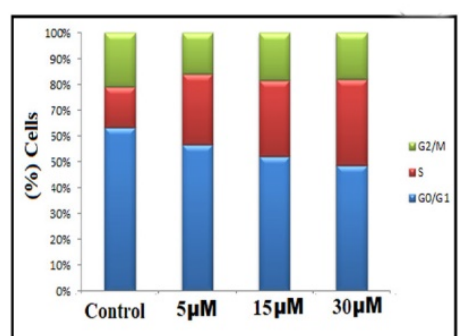

(F)

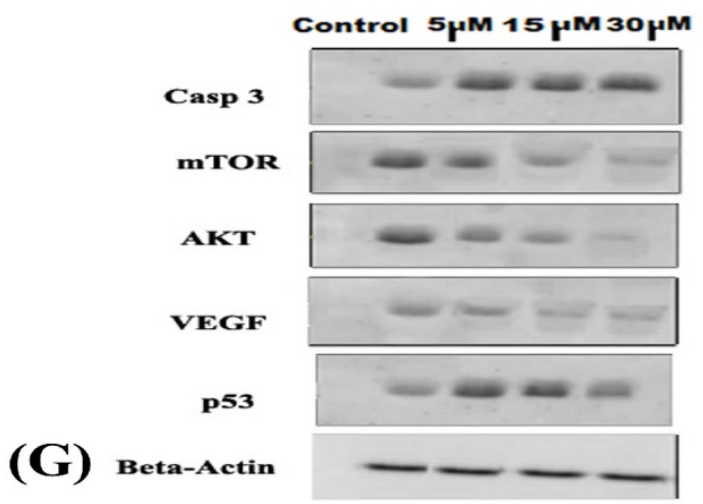

Figure 3. (A) Effects of ruthenium baicalein complex on HT-29 cell viability. Ruthenium baicalein complex at three different concentrations (5, 15 and $30 \mu \mathrm{M})$ were compared against the control at different time intervals. The complex at 15 and $30 \mu \mathrm{M}$ exhibited significant difference $(* * \mathrm{p}<0.01$ and $* \mathrm{p}<0.05)$ against the control. (B) Detection of apoptosis in HT-29 cells by Flow cytometry. In a double labelled system, the unfixed HT-29 cells, both ruthenium baicalein (5, 15 and $30 \mu \mathrm{M})$ treated and control were stained with PI and Annexin-V and analysed by flow cytometer. Dual parameter dot plot of Annexin-V ( $x$ axis) and PI ( $y$ axis) were shown. Quadrants: lower left (LL) - live cells, lower right (LR) - early apoptotic cells, upper right (UR) - late apoptotic cells, upper left (UL) - necrotic cells. (C) Percentage of apoptotic cells versus concentration. Three independent experiments were performed, $* \mathrm{P}<0.01$, significant difference between ruthenium baicalein complex $(5,15$ and $30 \mu \mathrm{M})$ and control. (D) Percentage of Annexin- $V$ positive cells. Three independent experiments were performed. $* \mathrm{P}<0.01$, significant difference between ruthenium baicalein complex $(5,15$ and $30 \mu \mathrm{M})$ and control. (E) Analysis of cell cycle phase distribution of HT-29 cells after the treatment with ruthenium baicalein complex (5, 15 and $30 \mu \mathrm{M}$ ) for $48 \mathrm{~h}$ by single label flowcytometry. The cells were fixed and DNA was labeled with PI. The histogram data represents the DNA content (x axis) versus cell number ( $y$ axis). Data is representative of three different experiments. (F) Quantitative of distribution of percentage of HT-29 cells in different phases of cell cycle. (G) Western blot analysis of expressions of p53, caspase-3, Akt, VEGF, and mTOR in HT-29 cells after treatment with ruthenium baicalein complex (5, 15 and 30 $\mu \mathrm{M})$. Data is representative of three different experiments.

\section{Ruthenium-baicalein complex binds with DNA successfully}

The addition of the CT-DNA to the complex showed a decrease in the absorbance of the baicaleinruthenium complex (Figure 2D). The decrease in the absorption of the resulting solution could be attributed to the alteration of the structure of DNA double helix after binding with the complex. The decrement of 0.05 in the absorption of the complex with the increasing concentrations of DNA indicated towards the non-intercalative mode such as outside binding of the complex with the CT-DNA.

\section{In-vitro studies}

\section{Ruthenium baicalein complex induces inhibition of cell viability of HT-29 cells}

The effect of the ruthenium baicalein complex on the viability of HT-29 cells is depicted in Figure 3A. A dose and incubation time dependent inhibitory effect was noted on the viability of HT-29 cells following treatment with ruthenium baicalein complex. The cell viability of the complex at $5 \mu \mathrm{M}, 10 \mu \mathrm{M}$ and $30 \mu \mathrm{M}$ after 48 hours was found to be $79.18 \%, 58.72 \%$ and $43.31 \%$ respectively as compared to the control $(p<0.01)$. Thus, it can be concluded that ruthenium 
baicalein complex inhibits the growth of HT-29 cells and the highest inhibition rate was found to be $56.69 \%$ at $30 \mu \mathrm{M}$ concentration of the complex at 48 hours.

\section{Ruthenium baicalein complex causes apoptosis and arrests the cell cycle in HT-29 cells and effects the expressions of p53, caspase-3, Akt, MTOR and VEGF}

Cells undergoing apoptosis were observed by staining them with Annexin- $\mathrm{V}$ and PI by treating the HT-29 cells with $5 \mu \mathrm{M}, 10 \mu \mathrm{M}$ and $30 \mu \mathrm{M}$ of the complex for 48 hours. Flow cytometry analysis can distinguish stained cells into four categories, namely viable (Annexin-V-PI-), early apoptosis (Annexin-V+ $\mathrm{PI}-$ ), late apoptosis (Annexin-V+PI+) and necrotic (Annexin-V-PI+) cells. Figure 3B demonstrates the distribution of cells undergoing treatment with different concentration $(5 \mu \mathrm{M}, 10 \mu \mathrm{M}$ and $30 \mu \mathrm{M})$ of the complex after 48 hours. Figure $3 \mathrm{C}$ shows that the percentages of apoptotic cell are $14 \%, 33.8 \%$ and $43.4 \%$ following treatment with $5 \mu \mathrm{M}, 10 \mu \mathrm{M}$ and $30 \mu \mathrm{M}$ of the complex as compared to control $(\mathrm{p}<0.01)$. Furthermore, a dose dependent increase in the populations of late apoptotic cells was also observed in HT-29 cells treated with $5 \mu \mathrm{M}, 10 \mu \mathrm{M}$ and $30 \mu \mathrm{M}$ of the complex after 48 hours (Figure $3 \mathrm{D}$ ). Thus, it is observed that HT-29 cells treated with the complex showed chromatin condensation and DNA fragmentation which signifies that complex can induce apoptosis in HT-29 cells.

Flow cytometry was also used to investigate the distribution of cell cycle phases with cellular DNA content. The apoptotic cells in the cell cycle histogram are represented by the number of sub-diploid cells (Figure 3E). The HT-29 cells that were treated with 5 $\mu \mathrm{M}$ of the complex demonstrates $56.7 \%$ cells in the G0/G1phase, whereas the cells treated with $10 \mu \mathrm{M}$ and $30 \mu \mathrm{M}$ of the complex exhibits $52.4 \%$ and $43.7 \%$ of cells in the G0/G1phase respectively (Figure 3F). Thus, it has been observed that the complex arrests the G0/G1phase of the cell cycle in a dose dependent manner.
The expression of proteins like p53, caspase-3, Akt, mTOR and VEGF were studied by Western blot analysis of HT-29 cells followed by treatment with different concentrations of ruthenium baicalein complex for 48 hours (Figure $3 \mathrm{G}$ ). A dose dependent downregulation of Akt, mTOR and VEGF were noted after treatment with $5 \mu \mathrm{M}, 10 \mu \mathrm{M}$ and $30 \mu \mathrm{M}$ of the complex for 48 hours. Subsequently, a distinguished increase in the expressions of p53 and Caspase- 3 were noted in HT-29 cells treated with $30 \mu \mathrm{M}$ concentration of the complex.

\section{Toxicity study}

\section{Acute and sub-acute toxicity study}

The $\mathrm{LD}_{50}$ dose of ruthenium-baicalein complex was found to be $400 \mathrm{mg} / \mathrm{kg}$. Assessing the $\mathrm{LD}_{50}$ doses, sub-acute toxic doses were selected as $50 \mathrm{mg} / \mathrm{kg}$, $100 \mathrm{mg} / \mathrm{kg}, 200 \mathrm{mg} / \mathrm{kg}$ and $400 \mathrm{mg} / \mathrm{kg}$. No treatment related mortality was found in animals treated with $50,100,200$ and $400 \mathrm{mg} / \mathrm{kg}$ of the complex in 28 days sub-acute toxicity study.

\section{Hematological and serum biochemical analysis}

The hematological serum biochemical profile of the control and 50, 100, 200 and $400 \mathrm{mg} / \mathrm{kg}$ complex treated groups is depicted in the tables 4,5,6 and 7. At $400 \mathrm{mg} / \mathrm{kg}$ of ruthenium-baicalein complex WBC, RBC levels were significantly increased as compared to the control group. At the end of 28 days of sub-acute toxicity study ALT, AST, ALP was significantly increased at higher dose levels (400 $\mathrm{mg} / \mathrm{kg}, \mathrm{p}<0.05)$ compared to control group. But the cholesterol and creatinine levels were maintained in the normal range $(p<0.05)$. Compared to control group glucose and Blood urea nitrogen were significantly increased at $400 \mathrm{mg} / \mathrm{kg}(\mathrm{p}<0.05)$. Thus, it can be concluded that $400 \mathrm{mg} / \mathrm{kg}$ of the complex induces toxicity in animals to an extent and hence should not be considered as a safe dose for the subsequent studies.

Table 4. Haematological findings in male rats treated with ruthenium baicalein complex for 28 days

\begin{tabular}{|c|c|c|c|c|c|}
\hline Parameters & Control & Ru-B50 mg/kg & Ru-B100 mg/kg & Ru-B200 mg/kg & Ru-B400 mg/kg \\
\hline Aspartate aminotransferase (AST) & $51.23 \pm 7.89$ & $51.87 \pm 9.61$ & $51.92 \pm 9.31$ & $55.87 \pm 8.17$ & $109.97 \pm 7.17^{*}$ \\
\hline Alanine aminotransferase (ALT) & $37.21 \pm 2.14$ & $37.52 \pm 2.34$ & $38.99 \pm 2.25$ & $40.17 \pm 0.02$ & $99.92 \pm 10.21^{*}$ \\
\hline Alkaline phosphatase (ALP) & $78.15 \pm 15.12$ & $66.27 \pm 15.12$ & $78.89 \pm 15.48$ & $61.17 \pm 33.85$ & $101.00 \pm 56.07^{*}$ \\
\hline Total protein $(\mathrm{g} / \mathrm{dl})$ & $5.45 \pm 0.16$ & $6.72 \pm 0.18$ & $6.84 \pm 0.20$ & $6.19 \pm 0.14$ & $2.17 \pm 0.32^{*}$ \\
\hline Albumin (g/dl) & $4.02 \pm 0.16$ & $3.92 \pm 0.21$ & $3.85 \pm 0.09$ & $3.48 \pm 0.22$ & $6.17 \pm 0.07^{*}$ \\
\hline Globulin (g/dl) & $4.08 \pm 0.16$ & $4.02 \pm 0.15$ & $3.92 \pm 0.03$ & $3.78 \pm 0.23$ & $4.07 \pm 0.13$ \\
\hline Total bilirubin (mg/dl) & $0.47 \pm 0.06$ & $0.42 \pm 0.08$ & $0.59 \pm 0.12$ & $0.49 \pm 0.09$ & $2.12 \pm 0.03^{*}$ \\
\hline Blood urea nitrogen (mg/dl) & $15.27 \pm 2.98$ & $17.06 \pm 2.87$ & $15.88 \pm 2.37$ & $15.87 \pm 2.96$ & $28.89 \pm 1.16^{*}$ \\
\hline Creatinine $(\mathrm{mg} / \mathrm{dl})$ & $0.59 \pm 0.09$ & $0.63 \pm 0.13$ & $0.60 \pm 0.09$ & $0.62 \pm 0.22$ & $1.59 \pm 0.19^{*}$ \\
\hline
\end{tabular}

Standard error mean = standard deviation (SD)/ $\sqrt{ }$ Total subject. Results were analysed by $\mathrm{t}$ test and one-way ANOVA and confirmed by Dunett's multiple comparison tests. $\mathrm{MCV}$ - mean corpuscle value, MCH- mean corpuscle haemoglobin, MCHC- mean corpuscle haemoglobin concentration, RBC- red blood cell, WBC- white blood cell. * ${ }^{*}<0.05$ significant difference when compared to the control group. 
Table 5. Haematological findings in female rats treated with ruthenium baicalein complex for 28 days

\begin{tabular}{|c|c|c|c|c|c|}
\hline Parameters & Control & Ru-B50 mg/kg & Ru-B100 mg/kg & Ru-B200 mg/kg & Ru-B400 mg/kg \\
\hline Haemoglobin $(\mathrm{Gm} \%)$ & $11.92 \pm 0.06$ & $11.98 \pm 0.079$ & $12.27 \pm 0.05$ & $12.42 \pm 0.06$ & $12.58 \pm 0.01$ \\
\hline Total RBC count $\left(\times 10^{6} / \mu \mathrm{l}\right)$ & $4.43 \pm 0.011$ & $4.47 \pm 0.012$ & $4.43 \pm 0.018$ & $4.27 \pm 0.04$ & $4.38 \pm 0.011$ \\
\hline WBC count $\left(\times 10^{3} / \mu \mathrm{l}\right)$ & $4.98 \pm 0.38$ & $5.22 \pm 0.19$ & $5.34 \pm 0.13$ & $5.41 \pm 0.11$ & $13.21 \pm 0.06^{*}$ \\
\hline Platelet count $\left(\times 10^{5} / \mu \mathrm{l}\right)$ & $6.08 \pm 0.48$ & $6.01 \pm 0.24$ & $6.88 \pm 0.27$ & $6.13 \pm 0.39$ & $6.15 \pm 0.19$ \\
\hline MCV (fL) & $90.12 \pm 1.08$ & $91.06 \pm 1.13$ & $91.22 \pm 1.42$ & $91.57 \pm 1.16$ & $90.97 \pm 1.13$ \\
\hline $\mathrm{MCH}(\mathrm{pg})$ & $29.17 \pm 0.09$ & $29.31 \pm 0.10$ & $28.31 \pm 0.16$ & $27.93 \pm 0.09$ & $29.02 \pm 0.04$ \\
\hline $\mathrm{MCHC}(\%)$ & $31.71 \pm 0.41$ & $31.93 \pm 0.62$ & $31.27 \pm 0.18$ & $32.92 \pm 0.29$ & $31.94 \pm 0.23$ \\
\hline Neutrophil (\%) & $51.62 \pm 0.11$ & $56.35 \pm 0.06$ & $47.11 \pm 0.15$ & $46.32 \pm 0.32$ & $53.06 \pm 0.11$ \\
\hline Eosinophil (\%) & $2.16 \pm 0.17$ & $2.25 \pm 0.24$ & $3.09 \pm 0.25$ & $2.54 \pm 0.12$ & $2.21 \pm 0.15$ \\
\hline Basophil (\%) & $0.00 \pm 0.00$ & $0.00 \pm 0.00$ & $0.00 \pm 0.00$ & $0.00 \pm 0.00$ & $0.00 \pm 0.00$ \\
\hline Lymphocyte (\%) & $34.19 \pm 1.14$ & $34.08 \pm 2.06$ & $29.27 \pm 1.11$ & $30.05 \pm 1.06$ & $34.16 \pm 1.58$ \\
\hline Monocyte (\%) & $3.78 \pm 0.74$ & $3.61 \pm 0.65$ & $3.62 \pm 0.59$ & $3.61 \pm 0.47$ & $2.84 \pm 0.83$ \\
\hline
\end{tabular}

Standard error mean = standard deviation $(\mathrm{SD}) / \sqrt{ }$ Total subject. Results were analysed by $\mathrm{t}$ test and one-way ANOVA and confirmed by Dunett's multiple comparison tests. $\mathrm{MCV}$ - mean corpuscle value, $\mathrm{MCH}$ - mean corpuscle haemoglobin, $\mathrm{MCHC}$ - mean corpuscle haemoglobin concentration, RBC-red blood cell, WBC- white blood cell. * $<<0.05$ significant difference when compared to the control group.

Table 6. Serum biochemical findings in male rats treated with ruthenium baicalein complex for 28 days

\begin{tabular}{|c|c|c|c|c|c|}
\hline Parameters & Control & Ru-B50 mg/kg & Ru-B100 mg/kg & Ru-B200 mg/kg & Ru-B400 mg/kg \\
\hline Aspartate aminotransferase (AST) & $51.27 \pm 8.18$ & $53.11 \pm 9.89$ & $51.34 \pm 9.11$ & $57.02 \pm 9.06$ & $112.12 \pm 8.19^{*}$ \\
\hline Alanine aminotransferase (ALT) & $38.45 \pm 2.65$ & $37.96 \pm 2.28$ & $37.52 \pm 2.15$ & $39.94 \pm 0.01$ & $101.02 \pm 11.22^{*}$ \\
\hline Alkaline phosphatase (ALP) & $76.68 \pm 15.25$ & $67.52 \pm 16.21$ & $78.52 \pm 15.02$ & $62.56 \pm 35.15$ & $103.00 \pm 53.11^{*}$ \\
\hline Total protein $(\mathrm{g} / \mathrm{dl})$ & $6.22 \pm 0.12$ & $6.02 \pm 0.21$ & $6.66 \pm 0.15$ & $6.14 \pm 0.10$ & $2.23 \pm 0.26^{*}$ \\
\hline Albumin $(\mathrm{g} / \mathrm{dl})$ & $3.88 \pm 0.12$ & $3.72 \pm 0.14$ & $3.51 \pm 0.09$ & $3.42 \pm 0.32$ & $6.02 \pm 0.04^{*}$ \\
\hline Globulin (g/dl) & $3.96 \pm 0.15$ & $3.82 \pm 0.15$ & $3.41 \pm 0.01$ & $3.30 \pm 0.19$ & $3.88 \pm 0.09$ \\
\hline Total bilirubin (mg/dl) & $0.45 \pm 0.09$ & $0.42 \pm 0.11$ & $0.68 \pm 0.07$ & $0.56 \pm 0.08$ & $2.02 \pm 0.06^{*}$ \\
\hline Blood urea nitrogen (mg/dl) & $15.98 \pm 2.98$ & $17.12 \pm 3.09$ & $16.11 \pm 3.12$ & $16.52 \pm 2.88$ & $30.17 \pm 1.28^{*}$ \\
\hline Creatinine $(\mathrm{mg} / \mathrm{dl})$ & $0.59 \pm 0.12$ & $0.65 \pm 0.17$ & $0.62 \pm 0.09$ & $0.67 \pm 0.11$ & $1.88 \pm 0.18^{*}$ \\
\hline
\end{tabular}

Standard error mean = standard deviation (SD)/ $\sqrt{ }$ Total subject. Results were analysed by $\mathrm{t}$ test and one way ANOVA and confirmed by Dunett's multiple comparison tests. * $\mathrm{p}<0.05$ significant difference when compared to the control group.

Table 7. Serum biochemical findings in female rats treated with ruthenium baicalein complex for 28 days

\begin{tabular}{|c|c|c|c|c|c|}
\hline Parameters & Control & Ru-B50 mg/kg & Ru-B100 mg/kg & Ru-B200 mg/kg & Ru-B400 mg/kg \\
\hline Aspartate aminotransferase (AST) & $48.62 \pm 9.84$ & $58.12 \pm 9.88$ & $44.24 \pm 13.15$ & $48.53 \pm 13.56$ & $104.36 \pm 24.45^{*}$ \\
\hline Alanine aminotransferase (ALT) & $38.56 \pm 4.54$ & $37.45 \pm 3.58$ & $40.46 \pm 1.94$ & $42.18 \pm 4.96$ & $97.92 \pm 6.42^{*}$ \\
\hline Alkaline phosphatase (ALP) & $68.51 \pm 24.59$ & $74.63 \pm 16.24$ & $85.62 \pm 9.31$ & $90.53 \pm 1.92$ & $148.64 \pm 41.58^{*}$ \\
\hline Total protein $(\mathrm{g} / \mathrm{dl})$ & $6.57 \pm 0.14$ & $6.15 \pm 0.18$ & $6.75 \pm 0.14$ & $6.45 \pm 0.11$ & $3.74 \pm 0.75^{*}$ \\
\hline Albumin (g/dl) & $4.04 \pm 0.18$ & $3.84 \pm 0.12$ & $3.48 \pm 0.15$ & $3.99 \pm 0.01$ & $5.95 \pm 0.44^{*}$ \\
\hline Globulin (g/dl) & $2.85 \pm 0.18$ & $2.75 \pm 0.35$ & $2.46 \pm 0.25$ & $2.48 \pm 0.48$ & $2.59 \pm 0.14$ \\
\hline Total bilirubin (mg/dl) & $0.24 \pm 0.04$ & $0.28 \pm 0.04$ & $0.35 \pm 0.01$ & $0.38 \pm 0.1$ & $1.64 \pm 0.14^{*}$ \\
\hline Blood urea nitrogen (mg/dl) & $15.23 \pm 2.15$ & $14.54 \pm 2.16$ & $14.58 \pm 2.15$ & $15.45 \pm 2.14$ & $27.34 \pm 1.47^{*}$ \\
\hline Creatinine (mg/dl) & $0.65 \pm 0.10$ & $0.64 \pm 0.02$ & $0.65 \pm 0.04$ & $0.67 \pm 0.05$ & $2.01 \pm 0.14^{*}$ \\
\hline
\end{tabular}

Standard error mean $=$ standard deviation $(\mathrm{SD}) / \sqrt{ }$ Total subject. Results were analysed by $\mathrm{t}$ test and one way ANOVA and confirmed by Dunett's multiple comparison tests. * $\mathrm{p}<0.05$ significant difference when compared to the control group.

\section{Histopathology}

Histopathological study showed the major morphological changes in the highest dose $(400$ $\mathrm{mg} / \mathrm{kg}$ ) group of mice and minor changes were observed at $200 \mathrm{mg} / \mathrm{kg}$ body weight of ruthenium baicalein complex. Histopathological examination of the kidney is depicted in Figure 4a. The treated groups of rats showed some histopathological alterations in kidney. The animals treated with doses 50 and $100 \mathrm{mg} / \mathrm{kg}$ (Figure 4a. D and E) did not show any major abnormalities compared to the control group, whereas slight thickening of the bowman's capsular membrane have been observed in the animals treated with dose of $200 \mathrm{mg} / \mathrm{kg}$ (Figure $4 \mathrm{a}$. C). At $400 \mathrm{mg} / \mathrm{kg}$ pyknotic nucleus (pn), vacuolization (v), thickening of the capsular membrane (tm), cytoplasmic debris (cd) and nodular sclerosis (n) were observed (Figure 4a.B). In a histopathological study of liver (Figure $4 b$ ), mice in the control group showed normal hepatic architecture (Figure $4 \mathrm{~b}$. A). Higher dose level $(400 \mathrm{mg} / \mathrm{kg})$ of ruthenium baicalein complex showed periportal mononuclear infiltrates (pmi), degeneration of hepatocytes (dh) and degeneration of vein (v) (Figure 4b. B), whereas at lower dose levels $200 \mathrm{mg} / \mathrm{kg}$ focal inflammation (fi) was observed (Figure 4b.C). Rest of the groups depicted normal architecture (Figure $4 \mathrm{~b}$. D and E). Figure 4c demonstrates the microscopic evaluation of stomach tissue (Figure 4c. A). At 400 and 200mg/kg dose of ruthenium-baicalein complex congestion (c), 
haemorrhages (h) and hyperplasia at gastric glandular area (hyp) were observed (Figure 4c. B and C). But at lower doses of $50 \mathrm{mg} / \mathrm{kg}, 100 \mathrm{mg} / \mathrm{kg}$ (Figure 4c. D and E) no histopathological alterations were observed. Figure $4 \mathrm{~d}$ demonstrates the microscopic evaluation of testis where the control group of animals (Figure 4d.A) showed the normal physiological architecture of testis. However, at 400 $\mathrm{mg} / \mathrm{kg}$ dose (Figure $4 \mathrm{~d} . \mathrm{B}$ ) testis showed degeneration in the seminiferous tubules (d), edema in the interstitial tissues (it) and hyperplasia (hyp) was noted in the groups treated with $200 \mathrm{mg} / \mathrm{kg}$ (Figure 4 d.C) of the complex. No structural abnormalities were found in animals treated with 50 and $100 \mathrm{mg} / \mathrm{kg}$ of the complex (Figure 4d. D and E). Similar observations are noted in the structural architecture of the animals denoting that $400 \mathrm{mg} / \mathrm{kg}$ dose should not be considered as a safe dose in the carcinogenicity study.

\section{In vivo carcinogenesis study}

\section{Ruthenium baicalein complex induces ACF in rats}

The animals from the normal control group did not show the presence of any $\mathrm{ACF}^{\prime}$ s but the animals treated with DMH and DSS displayed the presence of ACFs, that are identified as lesions in the colonic mucosal layer by their dark stain, elliptical shape, thick epithelial lining and perycriptal zone. The numbers of ACF were considerably lower in the in the complex treated groups than the DMH and DSS treated groups. A significant reduction in the ACF multiplicity was noticed in the $50 \mathrm{mg} / \mathrm{kg}$ and 100 $\mathrm{mg} / \mathrm{kg}$ complex treated groups as compared to the carcinogen control $(\mathrm{p}<0.05)$, but the most significant decrease was noted in the groups treated with 200 $\mathrm{mg} / \mathrm{kg}$ of the complex $(\mathrm{p}<0.01)$ [Figure 5(i)] (Table 8). A decrease of ACF multiplicity is noted in the animals after the complex treatment signifying that the ruthenium baicalein complex is capable of reversing the earliest signs of colorectal cancer.

\section{Histological analysis}

The histopathological examination of the colon tissues at the end of 20 weeks showed the formation of non-invasive carcinoma with lesions limited to mucosal layers of DMH and DSS treated animals (Figure 5 (ii) B). Luminal openings of the ACF are slightly elevated than the normal mucosa. The proliferating mucosal glands with ACF had slightly stratified nuclei with lack of goblet cells and depleted mucin. On the other hand, the animals treated with ruthenium baicalein complex demonstrated much lower incidences of carcinoma formation with a lower prevalence of hyperplasia as compared to the DMH and DSS treated animals (Figure 5 (ii) C-E). Animals treated with ruthenium and rifampicin $100 \mathrm{mg} / \mathrm{kg}$ (Figure 5(ii) $\mathrm{F}$ and $\mathrm{G}$ ) showed marked hyperplasia along with depletion of goblet cells and rupture of the mucosal lining. The decreasing incidences of carcinoma formation following complex treatment lead us to believe that the complex is effective against colorectal cancer.

\section{Ruthenium baicalein complex effects cellular antioxidant activity}

A decrease in SOD, CAT and reduced glutathione levels were found in the DMH + DSS treated rat colonic tissue [Figure 6 (iii)]. The animals treated with $200 \mathrm{mg} / \mathrm{kg}$ of the complex showed notable elevation of the SOD, CAT and glutathione levels in the colon tissues as compared to the carcinogen control as well as other treatment groups $(p<0.01)$. Reduced SOD, CAT and Glutathion levels provide us proof that the complex can also induce apoptosis through the reactive oxygen mediated pathway.

\section{Ruthenium baicalein complex effects the expressions of $B a x, B c \mid 2, W N T$ and $\beta$-catenin in rats}

The influence of the ruthenium baicalein complex treatment on the immunolocalization of proteins like Bax, Bcl2, WNT and $\beta$-catenin were observed by the immunohistochemical assay of each individual proteins (figure 5 iii, iv, v and vi) (Table 9). It was noted that the administration of DMH and DSS significantly reduced the expression of the Bax (Figure 5 (iii) B) whereas an upregulation in the expression of Bcl2 (Figure 5(iv) B), WNT (Figure (5v) B) and $\beta$-catenin (Figure 5 (vi) B) proteins were detected, as compared to the normal control rats $(\mathrm{p}<0.05)$. DMH and DSS treated animals supplemented with ruthenium baicalein complex considerably amplified the expression of Bax (Figure 5(iii) C-E), whereas expressions of $\mathrm{Bcl} 2, \mathrm{WNT}$ and $\beta$-catenin were significantly decreased (Figure 5 (iv) C-E, Figure 5 (v) $\mathrm{C}-\mathrm{E}$ and Figure 5 (vi) C-E) as compared to the carcinogen control $(p<0.05)$. The highest dose of ruthenium baicalein complex at $200 \mathrm{mg} / \mathrm{kg}$ body weight was vastly effective in increasing the expression of Bax and simultaneously decreasing the levels of $\mathrm{Bcl} 2$, WNT and $\beta$-catenin proteins $(\mathrm{p}<0.01)$ as compared to the carcinogen control. The expressions of the above protein markers lead us to observe that the complex induces apoptosis through the intrinsic pathway and also arrests cell cycle to effectively curb the progression of the disease. 



Figure 4. (a) Histopathological representation of Kidney of Sprague Dawley Rat. (A) Normal histopathological appearance of kidney tissue showing Bowman's capsule (bc), Macula densa (md), Proximal convoluted tubule (pct), Distal convoluted tubule (dct) of control Swiss Albino Mice (H\&E) 10X and 40X. (B) Histological appearance of kidney tissue of ruthenium-baicalein complex ( $400 \mathrm{mg} / \mathrm{kg})$ treated rat showing thickening of capsular membrane (tbm), ruptures ( $\mathrm{r}$ ), desquamated nuclei (dn), vacuolization (v), (H\&E) $10 X$ and 40 X. (C)Thickening of capsular membrane was observed at $200 \mathrm{mg} / \mathrm{kg}$ dose level of ruthenium-baicalein complex, (H\&E) $10 \mathrm{X}$ and 40X. (D)Histological appearance of kidney of ruthenium-baicalein complex (100 mg/kg) Swiss Albino Mice (H\&E) 10X and 40X. (E) Histological appearance of kidney of ruthenium-baicalein complex $(50 \mathrm{mg} / \mathrm{kg}$ ) Swiss Albino Mice(H\&E) 10X and 40X. (b) Histopathological representation of Swiss Albino Mice's liver. (A) Normal histological architecture of liver of control group showing the Central vein (cv), Bile duct (bd), Sinusoidal dilation (sd), Kupffer cell (kc), Lymph vessel (lv) of control Swiss Albino Mice(H\&E) 10X and 40X. (B) \& (C) Histological appearance of liver of ruthenium-baicalein complex (400 mg/kg and $200 \mathrm{mg} / \mathrm{kg}$ ) treated rats showing periportal mononuclear infiltrates (pmi), degeneration of hepatocytes (dh), focal inflammation (fi) (H\&E) 10X and 40X. (D) Histological appearance of liver of ruthenium-baicalein complex $(100 \mathrm{mg} / \mathrm{kg})$ treated mice $(\mathrm{H} \& \mathrm{E}) 10 \mathrm{X}$ and $40 \mathrm{X}$. (E) Histological appearance of liver of ruthenium-baicalein complex (50 mg/kg) treated mice (H\&E) 10X and 40X. (c) Representative histopathological picture of Swiss Albino Mice stomach. (A) Normal pathological architecture of stomach of control group showing Muscularis externa (me), Submucosa (sm), Muscularis mucosa (mm), Lamina propia (lp), Gastric pit (gp), epithelial lining (epl) of control Swiss Albino Mice (H\&E) 10X and 40X.(B) \& (C) Histological appearance of stomach of ruthenium-baicalein complex (400 mg/kg and $200 \mathrm{mg} / \mathrm{kg})$ treated mice showing Hemorrhages (h) between villus, Hyperplasia (hyp), leukocyte infiltration (Li) (H\&E) 10X and 40X. (D) Histological appearance of stomach of ruthenium-baicalein complex $(100 \mathrm{mg} / \mathrm{kg}$ ) treated mice (H\&E) 10X and 40X. (E) Histological appearance of stomach of ruthenium-baicalein complex (50 mg/kg) treated mice (H\&E) $10 X$ and 40X. (d) Representative histopathological picture of Swiss albino Mice testis. (A) Normal physiological architecture of testis of control Swiss albino Mice showing Sertoli cell (sc),Spermatogonia (Sp), Seminiferous tubule (St), Interstitial tissues (It) is seen within the tubular lumen. (H\&E) 4X and 10X.(B) Histopathological appearance of testis of ruthenium-baicalein complex $(400 \mathrm{mg} / \mathrm{kg})$ treated rat showing Edema in interstitial tissue (E), Degeneration of seminiferous tubule (D). (H\&E) $4 X$ and 10X.(C) Histopathological appearance of testis of ruthenium-baicalein complex $(200 \mathrm{mg} / \mathrm{kg})$ treated mice showing the degeneration of seminiferous tubules (D) and hyperplasia (Hyp). (H\&E) 4X and 10X.(D) Histological appearance of testis of ruthenium-baicalein complex (100 mg/kg) Swiss albino Mice (H\&E) 4X and 10X.(E) Histological appearance of testis of ruthenium-baicalein complex (50 mg/kg) Swiss albino Mice (H\&E) $4 X$ and $10 X$.

Table 8. ACF counting

\begin{tabular}{|c|c|c|c|c|c|c|}
\hline \multirow[t]{2}{*}{ Groups } & \multicolumn{5}{|c|}{ No. of crypts/ACF } & \multirow[t]{2}{*}{ Total number of ACF } \\
\hline & Crypt 1 & Crypt 2 & Crypt 3 & Crypt 4 & Crypt 5 & \\
\hline Control & $0.0 \pm 0.0$ & $0.0 \pm 0.0$ & $0.0 \pm 0.0$ & $0.0 \pm 0.0$ & $0.0 \pm 0.0$ & $0.0 \pm 0.0$ \\
\hline $\mathrm{DMH}+\mathrm{DSS}$ & $25 \pm 7.12$ & $32 \pm 6.53$ & $44 \pm 8.37$ & $38 \pm 2.2$ & $35 \pm 7.32$ & $174 \pm 31.54$ \\
\hline $\mathrm{DMH}+\mathrm{DSS}+\mathrm{Ru}-\mathrm{B} 50 \mathrm{mg} / \mathrm{kg}$ & $10 \pm 0.3$ & $14 \pm 5.2$ & $18 \pm 5.7$ & $12 \pm 4.1$ & $10 \pm 2.5$ & $64 \pm 177.8^{\star *}$ \\
\hline $\mathrm{DMH}+\mathrm{DSS}+\mathrm{Ru}-\mathrm{B} 100 \mathrm{mg} / \mathrm{kg}$ & $6 \pm 1.1$ & $12 \pm 2.01$ & $14 \pm 3.7$ & $10 \pm 1.7$ & $8 \pm 0.9$ & $50 \pm 9.41^{* *}$ \\
\hline $\mathrm{DMH}+\mathrm{DSS}+\mathrm{Ru}-\mathrm{B} 200 \mathrm{mg} / \mathrm{kg}$ & $10 \pm 0.6$ & $9 \pm 1.6$ & $10 \pm 2.3$ & $7 \pm 0.5$ & $4 \pm 1.9$ & $40 \pm 6.9^{* * *}$ \\
\hline $\mathrm{DMH}+\mathrm{DSS}+100 \mathrm{mg} / \mathrm{kg}$ Baicalein & $22 \pm 1.3$ & $31 \pm 2.05$ & $29 \pm 0.6$ & $26 \pm 3.1$ & $19 \pm 2.8$ & $127 \pm 9.85$ \\
\hline $\mathrm{DMH}+\mathrm{DSS}+100 \mathrm{mg} / \mathrm{kg}$ Ruthenium & $24 \pm 0.5$ & $21 \pm 2.9$ & $20 \pm 1.9$ & $17 \pm 1.5$ & $16 \pm 0.8$ & $98 \pm 7.6^{*}$ \\
\hline
\end{tabular}

All the data are expressed as mean \pm S.E. $n=6$. Results were analysed by $t$ test and one-way ANOVA and confirmed by Dunett's multiple comparison tests. ${ }^{*} \mathrm{p}<0.05$,

Significant difference between ruthenium $100 \mathrm{mg} / \mathrm{kg}$ and DMH and DSS control group, ${ }^{* *} \mathrm{p}<0.05$. Significant difference between Ru-B $50 \mathrm{mg} / \mathrm{kg}$ and Ru-B $100 \mathrm{mg} / \mathrm{kg}$ and $\mathrm{DMH}$ and DSS control group, ${ }^{* * *} \mathrm{p}<0.01$, Significant difference between Ru-B $200 \mathrm{mg} / \mathrm{kg}$ and DMH and DSS control group.

\section{Ruthenium Baicalein complex causes suppression of PCNA}

Figure 6 (i) denotes the effect of the ruthenium baicalein complex on the proliferation of cells in the colon tissues. The PCNA labeled cells can be easily identified with their distinct nuclear localization with 
a chromogen generating a brown stain thus making them quantifiable. Table 10 presents the percentage of PCNA labeled cells calculated as LI (labeling index). The PCNA-LI values markedly increased in the DMH and DSS treated rat colonic tissues (Figure 6(i) B) whereas a statistically significant decrease in the PCNA-LI values were noted in $200 \mathrm{mg} / \mathrm{kg}$ ruthenium baicalein complex treated groups $(\mathrm{p}<0.01)$ (Figure 6 (i)
E). Ruthenium at $100 \mathrm{mg} / \mathrm{kg}$ treated groups also demonstrated a decrease in the PCNA-LI values along with $100 \mathrm{mg} / \mathrm{kg}$ ruthenium baicalein complex treated groups $(\mathrm{p}<0.05)$ while the rest of the treated group showed no significant change in the expression of PCNA as compared to the carcinogen control group. Thus, ruthenium baicalein complex induces apoptosis in a dose dependant manner.
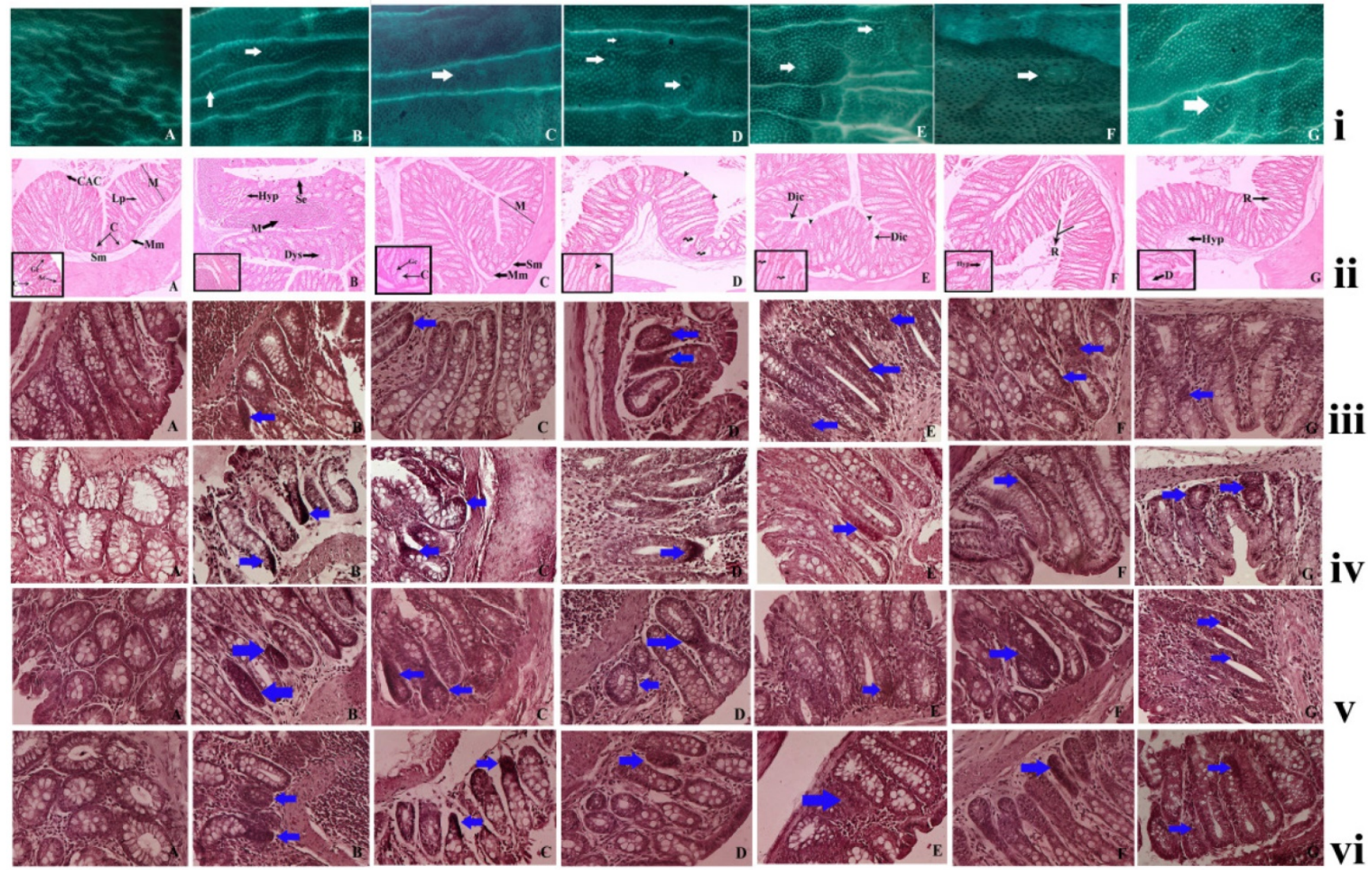

Figure 5. (i) Effect of ruthenium-baicalein complex on ACF. Topographical view of colon mucosa after staining the tissue with methylene blue. ACF were observed and distinguished from the surrounding normal crypts by their increased size, distance from the lamina to basal cell surfaces and pericryptalzone at $10 \times$ magnification. (A) colon mucosa of normal control group; (B) the DMH and DSS control group; (C) $200 \mathrm{mg} / \mathrm{kg}$ of ruthenium-baicalein complex treated group; (D and E) are the colon mucosa of animals treated with 100 and $50 \mathrm{mg} / \mathrm{kg}$ of ruthenium-baicalein complex, respectively; (F) ruthenium $100 \mathrm{mg} / \mathrm{kg}$ treated group and (G) baicalein $100 \mathrm{mg} / \mathrm{kg}$ treated group. The white arrows show the crypts. (ii) Histological study of colon mucosa of rats at 10X magnification [inset $40 \mathrm{X}$ ].(A). normal histological appearance of normal control rat (H\&E) showing the mucosal layer (M), muscularis mucosa (Mm), submucosal layer (Sm), lamina propia (Lp), crypt (C), columnar absorptive cells (Cac) 40X showing goblet cell $(\mathrm{Gc})$, absorption cell $(\mathrm{Ac})$. (B) histological appearance of DMH+DSS induced rat colon (H\&E) showing hyperplasia of mucosa (Hyp), depletion of mucin (M), sloughing of epithelial cells (Se), dysplasia (Dys), (C) histological appearance of DMH+DSS+200mg/kg ruthenium-baicalein (H\&E) showing almost normal appearance of rat colon, (D) and (E) histological appearance of DMH+DSS+100mg/kg Ru-RIF and DMH+DSS+50mg/kg Ru-RIF showing dilation of column (Dic), arrowhead showing discontinuation of absorption cells, curled arrow showing loss of goblet cells, (F) and (G) histological appearance of DMH+DSS+100mg/kg Ruthenium and DMH+DSS+100mg/kg baicalein (H\&E) showing occasional rupture (R), hyperplasia (Hyp), depletion of goblet cells (D). (iii) The immunohistochemical analysis of the Bax expression in the colon tissues of different groups of rats at $40 \mathrm{X}$ magnification. (A) the normal control group showing standard expression of Bax; (B) the DMH and DSS treated group showing no significant expression of Bax protein; (C) the ruthenium-baicalein complex treated with $200 \mathrm{mg} / \mathrm{kg}$ of complex showing significant expression of Bax; (D) and (E) are the ruthenium-baicalein of doses 100 and $50 \mathrm{mg} / \mathrm{kg}$ showing mild to moderate expression of Bax compared to the ruthenium-baicalein complex $200 \mathrm{mg} / \mathrm{kg}$ treated animals. (F) and (G) are the ruthenium and baicalein treated groups with weak expression of Bax. (vi) The immunohistochemical analysis of Bcl2 expression of different group of rats at $40 \mathrm{X}$ magnification. (A) The normal control group standard expression of $\mathrm{Bcl} 2$; (B) the DMH and DSS treated group showing strong expression of Bcl2 protein; (C) the ruthenium-baicalein complex treated with 200 $\mathrm{mg} / \mathrm{kg}$ of complex showing weak expression of $\mathrm{Bcl} 2$; (D) and (E) are the ruthenium-baicalein complex of doses 100 and $50 \mathrm{mg} / \mathrm{kg}$ treated groups showing mild expression of $\mathrm{Bcl} 2$, respectively; $(\mathrm{F})$ the ruthenium and $(\mathrm{G})$ the ruthenium-baicalein treated group showing moderate expression of $\mathrm{Bcl} / 2$. ( $\mathbf{v}$ ) The immunohistochemical analysis of WNT expression of different group of rats at 40X magnification. (A) The normal control group standard expression of WNT; (B) the DMH and DSS treated group showing strong expression of WNT protein; (C) the ruthenium-baicalein complex treated with 200 mg/kg of complex showing weak expression of WNT; (D) and (E) are the ruthenium-baicalein complex of doses 100 and $50 \mathrm{mg} / \mathrm{kg}$ treated groups showing mild expression of WNT, respectively; (F) the ruthenium and $(\mathrm{G})$ the ruthenium-baicalein treated group showing moderate expression of WNT. (vi) The immunohistochemical analysis of $\beta$-catenin expression of different group of rats at 40X magnification. (A) The normal control group standard expression of $\beta$-catenin; (B) the DMH and DSS treated group showing strong expression of $\beta$-catenin protein; (C) the ruthenium-baicalein complex treated with $200 \mathrm{mg} / \mathrm{kg}$ of complex showing weak expression of $\beta$-catenin; (D) and (E) are the ruthenium-baicalein complex of doses 100 and $50 \mathrm{mg} / \mathrm{kg}$ treated groups showing mild to moderate expression of $\beta$-catenin, respectively; (F) the ruthenium and (G) the ruthenium-baicalein treated group showing modest expression of $\beta$-catenin. 

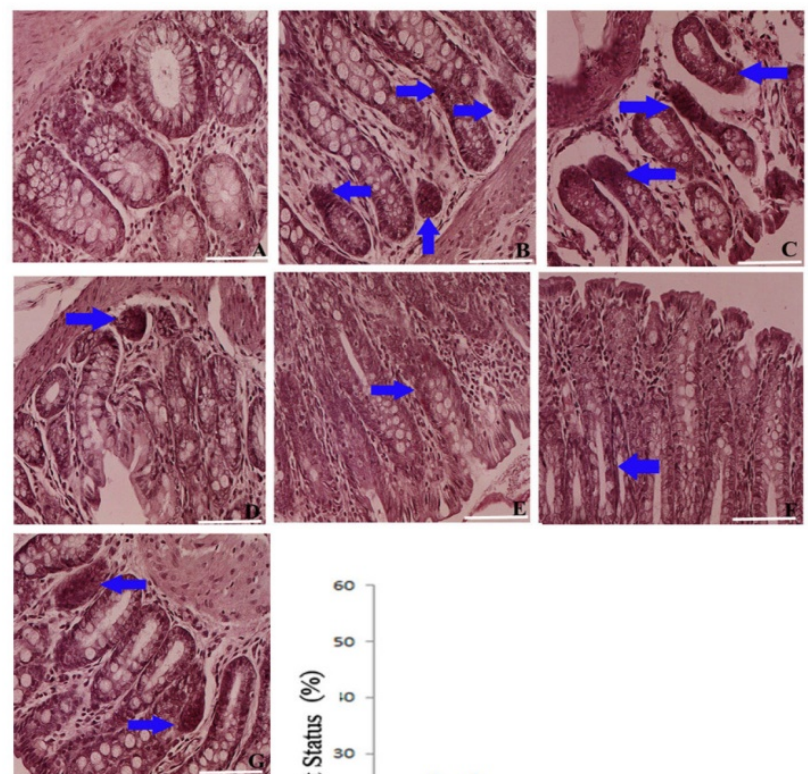

(i)
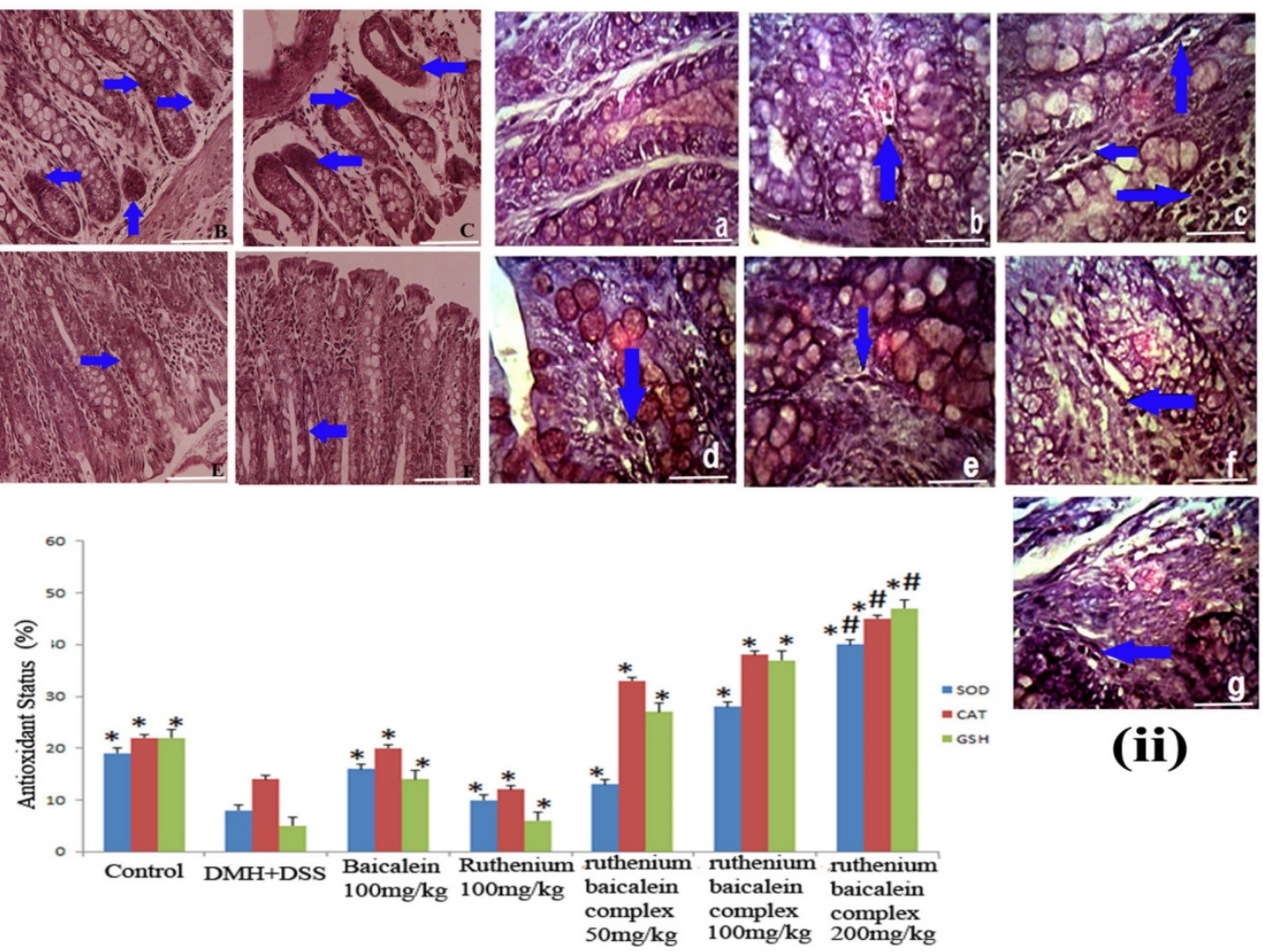

(1)

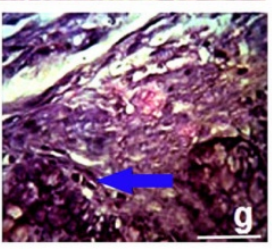

(ii)

(iii)

Figure 6. (i) The immunohistochemical analysis of expression of PCNA of different group of rats at 40X magnification. (A) the normal control group showing normal PCNA expression; (B) the DMH and DSS treated group showing strong expression of PCNA; (C) the ruthenium baicalein complex treated with 200 mg/kg of complex showing significant reduction in PCNA expression; (D) and (E) are the ruthenium baicalein of doses 100 and 50 mg/kg treated groups showing mild PCNA expression, respectively; $(F)$ the ruthenium; and $(G)$ the baicalein treated groups showing moderate PCNA expression. Approximately, 200 cells were counted per field, 10 fields were examined per slide. Ten slides were examined per group. (ii) The immunohistochemistry of TUNEL apoptotic cells at $40 X$ magnification. (a) The normal control group showing normal apoptosis; (b) the DMH and DSS treated group showing weak apoptosis; (c)the ruthenium baicalein complex treated with 200 $\mathrm{mg} / \mathrm{kg}$ of complex showing significant increase in apoptosis; (d) and (e) are the ruthenium baicalein of doses 100 and $50 \mathrm{mg} / \mathrm{kg}$ treated groups showing moderate apoptosis, respectively; (f) the ruthenium; and (g) the baicalein treated groups showing weak apoptosis. Approximately 700 cells were counted per field, 10 fields were examined per slide and 10 slides were examined per group.

\section{Ruthenium Baicalein complex induces apoptosis}

Figure 6(ii) denotes the effect of the ruthenium baicalein complex on apoptosis in the colonic tissue. The presence of brown stains, generated by DAB chromogen, coinciding with the condensed chromatin of apoptotic bodies denotes the TUNEL positive apoptotic cells. The control group animals exhibited a moderate level of apoptosis, whereas the incidence of apoptosis was theatrically lowered in the $\mathrm{DMH}$ and DSS treated colon tissues (Figure 6 (ii) B). In a field of about 700 cells, 2 to 4 apoptotic cells were found on an average in the DMH and DSS control group, whereas in the animals supplemented with ruthenium baicalein complex treatment apoptotic cells were found to increase profoundly (Figure 6(ii) C-E). An increase of upto 12-15 cells per 700 cells were noted in the $200 \mathrm{mg} / \mathrm{kg}$ of the complex treated groups. The apoptotic index represented by $\mathrm{AI}$ is considered in the Table 10. A significant increase $(p<0.01)$ in the percentage of apoptotic cells was noted in animals treated with $200 \mathrm{mg} / \mathrm{kg}$ of the complex as compared to the carcinogen control group. The ratio of cellular proliferation to apoptosis is represented by $R$ value. The observation from both TUNNEL and cell proliferation assay indicate that the early changes in the tumor microenvironment are accompanied by a parallel increase in cellular proliferation and reduction of apoptotic events. DMH and DSS treated group showed the highest value of $R$ however the $R$ value decreases comprehensively with the increase in ruthenium baicalein complex dose concentration. Taking together all these observations we can conclude that the complex induces apoptosis and correspondingly declines cellular proliferation in a dose dependent manner.

\section{Discussion}

Approximately, more than $50 \%$ of the populations are clinically prescribed platinum based compounds as anticancer chemotherapy [50]. In spite of the ubiquitous presence of platinum therapies in 
cancer treatments, countless drawbacks demand our exclusive attention. Besides, cancer cells can also gain resistance to such treatment over a period of time by the accumulation of mutations and epimutations [51]. Additionally, platinum agents are accompanied with various side-effects extending from minor to dose-limiting in toxicity [52]. The pioneers of the platinum based anticancer chemotherapy against colorectal cancers are Cisplatin and Oxaliplatin but the cure rate of colorectal cancer by such orthodox platinum drugs is virtually zero since such compounds impose vast side-effects owing to the increase in reactive oxygen species [53]. Furthermore, an increase in the repair mechanisms of platinum-DNA adducts inflicts the most widespread resistance to therapy. In order to circumvent these challenges, alternative and effective treatment strategies in colorectal cancers are the need of the hour.

An interesting alternative to metal based therapy in CRC are the bioflavonoids which are a class of polyphenols found in plant-based foods. Bioflavonoids have extensive anticarcinogenic properties attributed to their ability to induce differentiation and apoptosis, inhibition of metabolic carcinogen activation, cellular proliferation, tumor cell adhesion and angiogenesis [54]. Additionally, these molecules can chelate with a variety of metal ions to form complexes and these complexes possess greater radical scavenging properties as compared to the free flavonoids besides playing an important role in protection against oxidative stresses [55]. In the current study, we prospectively investigated the effects of the ruthenium baicalein complex on colon cancer using in vitro and in vivo models.

As a part of our investigation, we have synthesized, characterized and applied spectroscopic techniques to determine the antioxidant potential of the baicalein before and after complexation. The stoichiometric composition of the complex was confirmed by Job's method and the spectral data confirmed 5-hydroxy and 4-oxo site is the main domain to complex with the metal ruthenium in 1:2 molar ratios and the complex thus formed is crystalline in nature. The results obtained from the antioxidant study exhibited that the free radical scavenging activity of baicalein is significantly increased following metal complexation. Thus, ruthenium helps to alter the oxidative potential of baicalein after complexation by influencing its lower oxidation potential as compared to free baicalein. The interaction of the complex with CT-DNA resulted in a decrease in the UV-absorption spectra of free DNA, indicating towards the intercalation of the complex with CT-DNA.

In the next segment of our study, we endeavored to discover the effects of ruthenium baicalein complex on HT-29 human colon carcinoma cell line. Cell viability assay and oligonucleosomal fragmentation by DAPI staining designated that ruthenium baicalein complex can reduce cell proliferation and induce apoptosis. One of the most important targets for anticancer drugs is the regulation of cell cycle, especially; the arrest of G1 and G2 phases of cell cycle plays a pivotal role in the progression of the cell cycle [56]. To understand the mode of apoptosis induced by ruthenium baicalein complex the hypoploidy of cells were analyzed by flow cytometry using Annexin-V and PI staining. The double staining by Annexin-V and PI reveal that a higher percentage of early apoptosis is induced by ruthenium baicalein in the HT-29 cells (Figure 3B) by arresting the cells in G0/G1 phase (Figure 3E) which accordingly lead to apoptosis.

Table 9. Effect of ruthenium $(R u)$, baicalein $(B)$ and ruthenium baicalein complex (Ru-B) on the expression of $B a x, B c 12, W N T$ and $\beta$-catenin in colon tissues.

\begin{tabular}{lllll}
\hline Groups & Bax $\$$ & Bcl2\$ & WNT $\$$ & $\beta$-catenin $\$$ \\
\hline Control & $8.4 \pm 0.8$ & $7.3 \pm 0.2$ & $9.2 \pm 0.4$ & $8.5 \pm 0.7$ \\
DMH+DSS & $4.2 \pm 0.4$ & $22.6 \pm 1.3$ & $25.3 \pm 0.6$ & $20.0 \pm 0.4$ \\
Ru-B 50 mg/kg & $5.8 \pm 0.5^{* *}$ & $19.1 \pm 0.9^{* *}$ & $22.5 \pm 0.2$ & $17.1 \pm 0.6$ \\
Ru-B 100 mg/kg & $7.7 \pm 0.2^{*}$ & $13.6 \pm 0.2^{* *}$ & $11.3 \pm 0.7^{* *}$ & $10.3 \pm 0.1^{* *}$ \\
Ru-B 200 mg/kg & $10.3 \pm 1.7^{*}$ & $9.5 \pm 0.6^{*}$ & $8.5 \pm 0.1^{*}$ & $8.8 \pm 0.7^{*}$ \\
Baicalein 100mg/kg & $6.5 \pm 0.8$ & $12.4 \pm 0.9^{* *}$ & $13.0 \pm 0.6^{* *}$ & $12.7 \pm 0.4^{* *}$ \\
Ruthenium 100mg/kg & $5.8 \pm 0.7^{* *}$ & $10.8 \pm 0.8^{*}$ & $9.5 \pm 0.2^{*}$ & $10.5 \pm 0.6^{*}$ \\
\hline
\end{tabular}

$\S$ Each score represents the results of 6 slides per rat and 6 rats per group, mean \pm S.E. $(n=6)$. Each field were selected randomly for evaluation of percentage of immune-positive cells. * Significant difference between treated and carcinogen control $(p<0.01) .{ }^{* *}$ Significance difference between treated and carcinogen control $(\mathrm{p}<0.05)$.

Table 10. Cell proliferation and apoptosis in colon

\begin{tabular}{llll}
\hline Groups & PCNA-LI $\$$ & AI $(\%) \$$ & $R=$ PCNA-LI/AI \\
\hline Normal control & $17.5 \pm 0.6$ & $0.15 \pm 0.02$ & $116.66 \pm 0.5$ \\
DMH+DSS & $38.1 \pm 1.3$ & $0.08 \pm 0.02$ & $476.25 \pm 0.2$ \\
$\mathrm{Ru}-\mathrm{B} 50 \mathrm{mg} / \mathrm{kg}$ & $30.9 \pm 0.8$ & $0.09 \pm 0.01$ & $309.00 \pm 0.7$ \\
$\mathrm{Ru}-\mathrm{B} 100 \mathrm{mg} / \mathrm{kg}$ & $25.6 \pm 0.9^{* *}$ & $0.12 \pm 0.02^{\# \#}$ & $213.33 \pm 0.7 \$$ \\
$\mathrm{Ru}-\mathrm{B}$ 200 mg/kg & $18.2 \pm 0.8^{*}$ & $0.15 \pm 0.04^{\#}$ & $121.33 \pm 0.3 \$$ \\
Baicalein 100mg/kg & $27.1 \pm 0.02$ & $0.10 \pm 0.05$ & $271.00 \pm 0.2$ \\
Ruthenium 100mg/kg & $20.2 \pm 0.18^{* *}$ & $0.13 \pm 0.02^{\# \#}$ & $155.38 \pm 0.4^{\$ \$}$
\end{tabular}

$\mathrm{LI}=$ Labelling index, PCNA-LI= percentage of PCNA labelled cells/total number of cells counted, AI= Apoptotic index. $\mathrm{R}=\mathrm{PCNA}-\mathrm{LI} / \mathrm{AI}$. AI was calculated as the percentage of TUNEL positive cells/total number of cells counted. Values represents mean \pm S.E. § Total number of six slides were evaluated per rat. Each field consisted 700 cells. * Significant difference between PCNA-LI of Ru-B 200 $\mathrm{mg} / \mathrm{kg}$ vs carcinogen control animals $(\mathrm{p}<0.01)$. ${ }^{*}$ Significant difference between PCNA-LI of Ru 100 mg/kg, Ru-B 100 mg/kg vs carcinogen control animals $(\mathrm{p}<0.05)$. \# Significant difference between AI of Ru-B $200 \mathrm{mg} / \mathrm{kg}$ vs carcinogen control $(\mathrm{p}<0.01)$. \#\# Significant difference between AI of Ru $100 \mathrm{mg} / \mathrm{kg}, \mathrm{Ru}-\mathrm{B} 100$ $\mathrm{mg} / \mathrm{kg}$ vs carcinogen control animals $(\mathrm{p}<0.05) . \$$ Significant difference between $\mathrm{R}$ of Ru-B 200 mg/kg vs carcinogen control animals (p<0.01). $\$ \$$ Significant difference between R of Ru $100 \mathrm{mg} / \mathrm{kg}$, Ru-B $100 \mathrm{mg} / \mathrm{kg}$ vs carcinogen control animals $(\mathrm{p}<0.05)$

According to the global harmonized system of classification and labeling of chemicals, it is mandatory to report the safe dose of a new anticancer agent [57]. Therefore, acute and sub-acute toxicity 
study was conducted to evaluate the $\mathrm{LD}_{50}$ value of the complex along with its safe doses and treatment related mortality. Typical alterations were observed in serum and hematological parameters during the sub-acute toxicity study. Slight alterations were also observed in the architectural structure of kidney, stomach, and testis at a dose of $400 \mathrm{mg} / \mathrm{kg}$ of the complex.

To offer a deeper insight into the mechanism of action of the complex on a cellular level, a cell-based reporter assay was conducted to analyze the effect of the ruthenium baicalein complex on the activity of p53, VEGF, mTOR, Akt, and caspase-3 signaling pathways. One of the most commonly mutated genes in human cancers is the p53 [58].Studies reveals that mutations of the p53 gene play a crucial role in the transition of tumor pathological process during the formation of adenoma-carcinoma [59]. Cellular p53 levels modulate the expressions of PTEN, which is a negative regulator of the PI3 kinase pathway that deciphers signals from tyrosine kinase receptors to modify the cellular environment. Once PI3 is activated by PTEN it assists the phosphorylation of Akt and activates mTOR pathways which together, play a crucial role in tumor progression [60]. It is further noted that mTOR activates cyclins that regulate the activity of enzymes required for the passage of cells through G1-S phases of the cell cycle [61]. Besides this, mTOR also translates an increase of angiogenic factor like VEGF thus indirectly contributing towards the tumor growth in breast, cervical, ovarian, and gastrointestinal cancers [61]. Furthermore, p53 is capable of activating the caspase cascade via the intrinsic apoptotic pathway. Following p53 activation caspase-3, also known as the executioner caspase, degrade various cellular proteins in order to bring about the morphological changes necessary for apoptosis [62].

Our current study demonstrates that ruthenium baicalein complex modulates through a novel mechanism by upregulation of p53 and Caspase- 3 and downregulation of Akt, mTOR, and VEGF expressions. Thus, apoptosis is potentiated via the intrinsic pathway consequently by activating the caspase cascade in the cancer cells. Besides, the decrease of Akt, mTOR, and VEGF expression demonstrate that the complex is capable of preventing angiogenesis and promoting cell cycle arrest by restraining the G0/G1 phase in the cell cycle. Taken together these observations lead us to believe that the complex has a profound effect on the intrinsic apoptotic pathway of the tumor cells leading to the interruption of cellular proliferation. Our results have thus agreed with the previous reports and provide ample evidence that ruthenium baicalein complex follows a p53 dependent apoptosis in colon cancer cells.

Apoptosis proceeds in two different pathways namely extrinsic and intrinsic pathways that are regulated by several factors. The intrinsic pathway that takes place around mitochondria and one of the key proteins of this pathway is Bcl2, which competes with Bax resulting in the alteration of mitochondrial membrane potential and permeability leading to the release of regulatory proteins that can activate the cellular caspase cascade [63]. BCL-2 is an integral, membrane-associated protein with antiapoptotic and anti-oxidative effects where it plays a pivotal role in promoting cell survival and inhibiting the actions of pro-apoptotic proteins like Bax. Cancer is the result of over-expression of anti-apoptotic genes, and underexpression of pro-apoptotic genes. Over-expression of such anti-apoptotic proteins help in determining mitochondrial integrity and releases effector proteins that cease apoptosis resulting in cellular proliferation [64]. However, it is noted that at the same time the expression of pro-apoptotic proteins like Bax is significantly reduced by oncogenic kinases [65].We observed from our in-vivo study that the ruthenium baicalein complex treatment significantly decreased the Bcl2 expression whereas the expression of Bax were found to significantly increase in the colon tissues (Figure 5 iii and vi).

Another family of cell signaling molecules called the Wnt and its associated proteins plays an important role in the regulation of cell adhesion. In fact, misregulation of the Wnt pathway has a significant role in many human pathologies including cancer [66]. The Canonical Wnt pathway is known to be intricately involved in the development of benign and malignant tumors. The activation of the Wnt pathway is revealed by the presence of $\beta$-catenin in the nucleus or cytoplasm that can be identified by immuno-histochemical staining or Western blots [67]. An increase in $\beta$-catenin levels correlates with poor prognosis of cancer. We observed that the ruthenium baicalein complex treatment significantly decreased both Wnt and $\beta$-catenin levels in the colon tissue (Figure $5 \mathrm{v}$ and iv), thus signifying that the ruthenium baicalein complex has an influence on the Canonical Wnt signalling pathway.

Initiation of apoptosis by p53 activation also transpires by stimulating changes in the genes that modifies the redox mechanism of the cells, regulated by the mitochondrial function, to enhance the ROS mediated apoptotic pathway [60]. It is observed that ruthenium baicalein complex treatment, causes an elevation the levels of SOD, CAT, and GSH in the colon tissues by activating the mitochondrial ROS function to initiate apoptosis (Figure 2E). 
PCNA or Proliferating Cell Nuclear Antigen serves as a processivity-promoting factor in DNA replication and an uncharacteristic upsurge of PCNA leading to epithelial cell proliferation is an early manifestation of pre-neoplasia [68]. Studies reveal that the cellular level of PCNA is actively controlled by p53 [69]. In our study, the carcinogen controlled animals demonstrated an increase in the number of PCNA labeled cells along with reduced AI (Apoptotic Index) values (Table 10) which indicates cellular proliferation and larger ACF multiplicity within the colon mucosa. However, treatment with ruthenium baicalein complex resulted in a substantial decrement of PCNA labeled cells and increased AI value. Taking these observations into consideration we can conclude that ruthenium baicalein complex therapy upregulated the p53 expression that in turn is responsible for the suppression of PCNA, resulting in reduced proliferation along with ACF multiplicity and increased apoptotic events in the colon tissues.

Taken together, our work uncovered novel molecular mechanism of ruthenium baicalein complex responsible for the p53 mediated apoptosis in the colon cancer cells. Apoptosis is initiated by the activation of the intrinsic apoptotic pathway mediated by the Bcl2 and Bax proteins under the influence of activated p53 and simultaneously down regulating the Akt/mTOR and canonical WNT/ $\beta$-catenin pathways. Furthermore, the complex also exerts antiangiogenic activity by down regulating the VEGF proteins, resulting in a decrease of ACF multiplicity in the colon cancer cells. Besides these, the complex has a profound effect on the anti-oxidant potential of the cancer cells due to the activation of mitochondrial ROS under the influence of p53. The decrease of PCNA as a result of p53 activation further potentiate apoptosis by reducing cellular proliferation (Figure 7).

Regardless of the stupendous advancement of

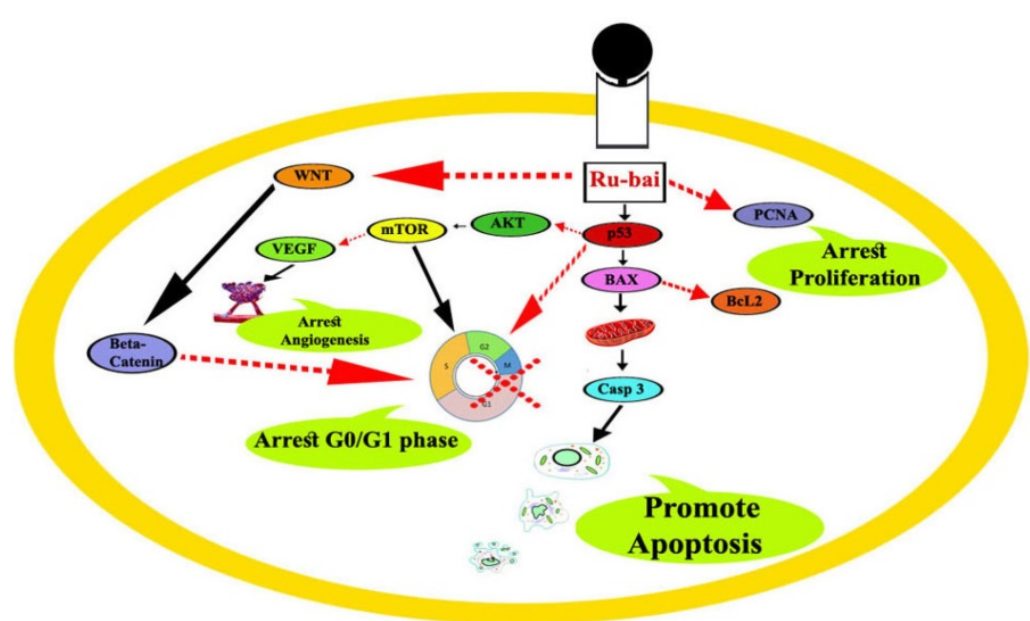

Figure 7. Probable molecular mechanistic pathway of ruthenium baicalein complex technology, the treatment strategy against colon cancer is still to gain substantial momentum and hence novel approaches to eradicate the disease is the need of the hour. The present combinatorial treatment approach demonstrates higher efficacy at substantially lower doses and imparts minimal toxicity or other side effects, as supported by our findings. The in vitro and in vivo results provide substantial evidence that low doses of ruthenium baicalein chemotherapy could suspend, reverse or interrupt the progression of colon cancer by locating the biomarkers accompanying the induction of apoptosis in the colon cancer cells by regulating intrinsic apoptosis as well as antiangiogenic pathway, thus serving as a potential candidate for cancer therapy in clinical settings in the near future.

\section{Abbreviations}

FT-IR (Fourier Transform Infrared Spectroscopic Analysis), NMR (Nuclear Magnetic Resonance), IR (Infrared Spectroscopy), XRD (X Ray Diffraction Spectroscopy), PCNA (proliferating cell nuclear antigen), VEGF (vascular endothelial growth factor), mTOR (mammalian target of rapamycin), ACF (aberrant crypt foci).

\section{Acknowledgments}

The authors are highly obliged to Haricharan Garg Charitable Trust for their financial support in this study work. The authors would also like to thank Ashoka Laboratories and Mr. Pravanjan Bhakta for their esteemed support.

\section{Authors' contributions}

YB and LB conceived the study and participated in its design and co-ordination. TC performed cell culture and cellular assays. TG and PC carried out animal experiments and sample collection. SR participated in cell culture, statistical analysis and designed the manuscript. All authors read and approve the final manuscript.

\section{Ethical approval for animal experimentation}

The whole experimental protocol involving animals was performed as per the recommendations of the Institutional Animal Ethics Committee \& by the Animal Regulatory Body of the government. (Regd No. 1458/PO/a/11/CPCSEA).

\section{Competing Interests}

The authors have declared that no competing interest exists. 


\section{References}

1. Siegel R, Ma J, Zou Z, Jemal A. Cancer statistics, 2014. CA Cancer J Clin. 2014;64:9-29.

2. Sung J. Colorectal cancer screening: it's time for action in Asia. Cancer Detect Prev 2007; 31(1): 1-2.

3. Jemal A, Bray F, Center MM, Ferlay J, Ward E, Forman D. Global cancer statistics. CA Cancer J Clin 2011; 61(2): 69-90.

4. Mohandas KM. Colorectal cancer in India: Controversies, enigmas and primary prevention. Indian J Gastroenterol 2011; 30(1): 3-6.

5. Patil PS, Saklani A, Gambhire P, Mehta S, Engineer R, Desouza A. et.al, Colorectal cancer in India; An Audit from a tertiary center in a low prevalence area. Indian J Surg Oncol 2017; 8(4) :484-490.

6. Delinger CS, Barsevick AM. The challenges of colorectal cancer survivorship. J Natl Canc Netw 2009; 7(8): 883-894.

7. Rafique S, Idrees M, Nasim A, Akbar H, Athar A. Transition metal complexes as potential therapeutic agents. Biotechnol Mol Biol Rev 2010; 5(2): 38-45.

8. Sharma AR, Gangrade DM, Bakshi SD, John JS. Ruthenium complexes:Potential candidate for anti- tumour activity. Int J Chemtech Res 2014; 6(1): 828-837.

9. Johnstone TC, Suntharalingam K., Lippard SJ. Third row transition metals for the treatment of cancer. Philos Trans A Math Phys Eng Sci 2015; 373(2037):20140185.

10. Kathawala RJ, Gupta P, Ashby Jr. CR, Chen ZS. The modulation of ABC transporter-mediated multidrug resistance in cancer: a review of the past decade. Drug Resist Updat 2014; 18: 1-17.

11. Antonarakis ES and Emadi A. Ruthenium-based chemotherapeutics: are they ready for prime time? Cancer Chemother Pharmacol 2010; 66(1): 1-9.

12. Bergamo A, Gaiddon C, Schellens JHM, Beijnen JH, Sava G. Approaching tumour therapy beyond platinum drugs status of the art and perspectives of ruthenium drug candidates. J Inorg Biochem 2012; 106(1): 90-99.

13. Dickson NR, Jones SF, Burris HA, Ramanathan RK, Weiss GJ, Infante JR. et.al. A phase 1 dose- escalation study of NKP-1339 in patients with advanced solid tumors refractory to treatment. J Clin Oncol 2011; 29(15) : 2607.

14. Hartinger CG, Jakupec MA, Groessl M, Zorbas-seifried S, Berger W, Egger A. et.al., KP1019, a new redox-active anti-cancer agent-preclinical development and results of a clinical phase 1 study in tumor patients. Chem Biodivers 2008; 5(10): 2140-2155.

15. Donald G, Hertzer K, Eibl G. Baicalein-an intriguing therapeutic phytochemical in pancreatic cancer. Curr Drug Targets 2012; 13(14): 1772-1776.

16. Giovannucci E, Stampfer MJ, Colditz GA, Rimm EB, Trichopoulos D, Rosner $\mathrm{BA}$, et al. Folate, methionine and alcohol intake and risk of colorectal adenoma. J Natl Cancer Inst 1993; 85(11): 875-884.

17. Platz EA, Willett WC, Colditz GA, Rimm EB, Spiegelman D, Giovannucci E. Proportion of colon cancer risk that might be preventable in a cohort of middle-aged US men. Cancer Causes Control 2000; 11(7) : 579-588.

18. Roy S, Das R, Ghosh B, Chakraborty T. Deciphering the biochemical and molecular mechanism underlying the in vitro and in vivo chemotherapeutic efficacy of ruthenium quercetin complex in colon cancer. Mol Carcinog 2018; 57(6): 700-721.

19. Zhang S, Wang X, Sagawa K, Morris ME. Flavonoids chrysin and benzoflavone, potent breast cancer resistance protein inhibitors, have no significant effect on topotecan pharmacokinetics in rats or mdr1a/1b (-/-) mice. Drug Metab Dispos 2005; 33(3): 341-348.

20. Atmani D, Chaher N, Atmani D, Berboucha M, Debbache N, Boudaoud H. Flavonoids in human health: from structure to biological activity. Curr Nutr Food Sci 2009; 5(4): 225-237.

21. Mu J, Liu T, Jiung $\mathrm{L}, \mathrm{Wu} \mathrm{X}, \mathrm{Cao} \mathrm{Y}, \mathrm{Li} \mathrm{M}$ et.al. The traditional Chinese medicine baicalein potently inhibits gastric cancer cells. J Cancer 2016; 7(4): 453-461.

22. Kim H, Yiluo H, Park S, Lee JY, Cho E. Characterization and enhanced antioxidant activity of the cysteinyl $\beta$-cyclodextrin-baicalein inclusion complex. Molecules 2016; 21(6): 703.

23. Li HL, Zhang S, Wang Y, Liang RR, Li J, An P. et.al. Baicalein induces apoptosis via a mitochondrial-dependent caspase activation pathway in T24 bladder cancer cells. Mol Med Rep 2013; 7(1): 266-270

24. Po LS, Chen ZY, Tsang DS, Leung LK. Baicalein and genistein display differential actions on estrogen receptor (ER) transactivation and apoptosis in MCF-7 cells. Cancer Lett 2002; 187(1-2): 33-40

25. Kim SJ, Kim HJ, Kim HR, Lee SH, Cho SD, Choi CS. et.al. Antitumor actions of baicalein and wogonin in HT-29 human colorectal cancer cells. Mol Med Rep 2012; 6(6): 1443-1449

26. Wang CZ, Zhang CF, Chen L, Anderson S, Lu F, Yuan CS. Colon cancer chemopreventive effects of baicalein, an active enteric microbiome metabolite from baicalin. Int J Oncol 2015; 47(5) : 1749-1758.

27. Lin $\mathrm{CL}$, Jeng $\mathrm{JH}$, Wu CC, Hsieh SL, Huang GC, Leung $\mathrm{W}$, et al, Chemopreventive potential of 2,3,5,4 Tetrahydroxystilbene-2-O- $\beta$-Dglucoside on the formation of aberrant crypt foci in Azoxymethane-induced colorectal cancer in rats. BioMed Res Int 2017; 3634915: 1-8.

28. Ray RS, Ghosh B, Rana A, Chatterjee M. Suppression of cell proliferation, induction of apoptosis and cell cycle arrest: Chemopreventive activity of vanadium in vivo and in vitro. Int J Cancer 2007; 120(1): 13-23.
29. Li W, Wang QL, Liu X, Dong SH, Li HX, Li CY et.al. Combined use of vitamin D3 and metformin exhibits synergistic chemopreventive effects on colorectal neoplasia in rats and mice. Cancer Prev Res 2015; 8(2): 139-148.

30. Hayrezaie M, Shams K, Moghadamtousi SZ, Karimian H, Hassandarvish P, Emtyazjoo M, et al. Chemoprevention of colonic aberrant crypt foci by novel schiff based dichlorido(4-methoxy-2-\{[2-(piperazin-4-Ium-1-Yl) ethyl] iminomethyl\} phenolate) $\mathrm{Cd}$ complex in azoxymethane-induced colorectal cancer in rats. Sci Rep 2015; 5(12379): 1-15.

31. Mousa L, Salem ME, Mikhail S. Biomarkers of angiogenesis in colorectal cancer. Biomark. Cancer 2015; 7(S1): 13-19.

32. Baskar AA, Ignacimuthu S, Paulraj GM, Al Numair KS. Chemopreventive potential of beta-sitosterol in experimental colon cancer model - an in vitro and in vivo study. BMC Complement Altern Med 2010; 10(1):10:24.

33. Perse $\mathrm{M}$ and Cerar $\mathrm{A}$. The dimethylhydrazine induced colorectal tumours in rat- experimental colorectal carcinogenesis. Radiol Oncol 2005; 39(1) : 61-70.

34. Tanaka T. Development of an Inflammation-Associated Colorectal Cancer Model and Its Application for Research on Carcinogenesis and Chemoprevention. Int J Inflam 2012; 658786: 1-16.

35. Okayasu I, Hatakeyama S, Yamada M, Ohkusa T, Inagaki Y, Nayaka R. A novel method in the induction of reliable experimental acute and chronic ulcerative colitis in mice. Gastroenterology 1990; 98(3) :694-702.

36. Dolatabadi JEN, Mokhtarzadeh A, Ghareghoran SM, Dehghan G. Synthesis, Characterization and Antioxidant Property of Quercetin-Tb (III) Complex. Adv Pharm Bull 2014; 4(2): 101-104.

37. Benzie IF and Strain JJ. The ferric reducing ability of plasma (FRAP) as a measure of "antioxidant power": the FRAP assay. Anal Biochem 1996; 239(1):70-76.

38. Pennycooke JC, Cox S, Stushnoff C. Relationship of cold acclimation, total phenolic content and antioxidant capacity with chilling tolerance in petunia (Petunia $\times$ hybrid). Environ Exp Bot 2005; 53: 225-232.

39. Dehghan G, Dolatabadi JEN, Jouyban A, Zeynali KA, Ahmadi SM, Kashanian S. Spectroscopic studies on the interaction of quercetin-Tb (III) complex with calf thymus DNA. DNA Cell Biol 2011; 30: 195-201.

40. Stevens JJ, Graham-Evans B, Walker AM, Armstead B, Tchounwou PB. Cytotoxic effect of arsenic trioxide in adenocarcinoma colorectal cancer (HT-29) cells. Metal Ions in Biology and Medicine 2008;10: 458-462.

41. Li H, Wang Q, Dong L, Liu C, Sun Z, Gao L, Wang X. Morusin suppresses breast cancer cell growth in vitro and in vivo through $C / E B P \beta$ and PPARY mediated lipoapoptosis. J Exp Clin Cancer Res 2015; 34:137-149.

42. Deng XH, Song HY, Zhou YF, Yuan GY, Zheng F.J. Effects of quercetin on the proliferation of breast cancer cells and expression of survivin in vitro. Exp Ther Med 2013; 6(5):1155-1158.

43. Ghosh N, Sandur R, Ghosh D, Roy S, Janadri S. Acute, 28days sub acute and genotoxic profiling of Quercetin-Magnesium complex in Swiss albino mice. Biomed Pharmacother 2017; 86 :279-291.

44. Tsunoda A, Shibusawa M, Tsunoda Y, Yokoyama N, Nakao K, Kusano M. et.al. Antitumor effect of S-1 on DMH induced colon cancer in rats. Anticancer Res 1998; 18(2A) : 1137-1141

45. Jagatheesh K, Arumugam V, Elangovan N, Pavankumar P. Evaluation of the anti-tumor and antioxidant activity of Amorphophallus paeonifolius on DMBA induced mammary carcinoma. J Chem Pharm Sci 2010;1(2).

46. Sinha BBP, Peterson GA, Li GC, Whitney RR. Nuclear change distribution of isotone pairs I. 31P and 32S. Physical Review C 1972; 6: 1657-1663

47. Awasthi S, Kakkar P, Viswanathan PN, Bharadwaj R. Effect of anesthetic ether on lipid peroxidation and superoxide dismulataseisozymes of young and adult rat brain. Indian J Exp Biol 1989; 27(7): 647-649.

48. Rotruck JT, Pope AL, Ganther HE, Swanson AB, Hafeman DG, Hoekstra WG. Selenium: biochemical role as a component of glutathione peroxidase. Science 1973; 179(4073): 588-590.

49. Roy S, Sil A, Chakraborty T. Potentiating apoptosis and modulation of p53, Bcl2, and Bax by a novel chrysin ruthenium complex for effective chemotherapeutic efficacy against breast cancer. J Cell Physiol 2018; 1-22.

50. Johnstone TC, Park GY, Lippard SJ. Understanding and Improving Platinum Anticancer Drugs - Phenanthriplatin. Anticancer Res 2014; 34(1): 471-476.

51. Chabner BA, Roberts TG Jr. Timeline: Chemotherapy and the war on cancer. Nat Rev Cancer 2005; 5(1): 65-72.

52. Kelland L. The resurgence of platinum-based cancer chemotherapy. Nat Rev Cancer 2007; 7(8): 573-584

53. Mármol I, Sánchez-de-Diego C, Dieste AP, Cerrada E, Rodriguez Yoldi MI. Colorectal Carcinoma: A General Overview and Future Perspectives in Colorectal Cancer. Int J Mol Sci 2017; 18(1): 197.

54. de Kok TM, van Breda SG, Manson MM. Mechanisms of combined action of different chemopreventive dietary compounds: a review. Eur J Nutr 2008 ; 47 Suppl 2: 51-59.

55. Symonowicz M, Kolanek M. Flavonoids and their properties to form chelate Complexes. Biotechnol Food Sci 2012; 76 (1): 35-41.

56. Muthurajan T, Rammanohar P, Rajendran NP, Sethuraman S, Krishnan UM. Evaluation of a quercetin-gadolinium complex as an efficient positive contrast enhancer for magnetic resonance imaging. RSC Adv 2015; 5: 86967-86979

57. Hajrezaie M, Hassandarvish P, Moghadamtousi SZ, Gwaram NS, Golbabapour S, Najihussien et al. Chemopreventive evaluation of a Schiff base derived copper (II) complex against azoxymethane-induced colorectal cancer in rats. Plos ONE 2014; 9: e91246. 
58. Kandoth C, McLellan MD, Vandin F, Ye K, Niu B, Lu C et al. Mutational landscape and significance across 12 major cancer types. Nature 2013; 502(7471): 333-339

59. López I, P Oliveira L, Tucci P, Alvarez-Valín F, A Coudry R, Marín M. Different mutation profiles associated to P53 accumulation in colorectal cancer. Gene 2012; 499(1): 81-87.

60. Fridman JS, Lowe SW. Control of apoptosis by p53. Oncogene 2003; 22(56): 9030-9040.

61. Advani SH. Targeting mTOR pathway: a new concept in cancer therapy. Indian J Med Paediatr Oncol 2010; 31(4): 132-136.

62. Zhuo Z, Hu J, Yang X, Chen M, Lei X, Deng L et al. Ailanthone inhibits Huh7 cancer cell growth via cell cycle arrest and apoptosis in vitro and in vivo. Sci Rep 2015; 5: 16185.

63. Wang J, Qi L, Zheng S, Wu T. Curcumin induces apoptosis through the mitochondria-mediated apoptotic pathway in HT-29 cells. J Zhejiang Univ Sci B 2009; 10(2): 93-102.

64. Donovan M, Cotter TG. Control of mitochondrial integrity by Bcl-2 family members and caspase-independent cell death. Biochim Biophys Acta 2004; 1644(2-3): 133-147.

65. Adams JM, Cory S. The Bcl-2 apoptotic switch in cancer development and therapy. Oncogene 2007; 26(9): 1324-1337.

66. Amin N, Vincan E. The Wnt signaling pathways and cell adhesion. Front Biosci (Landmark Ed). 2012; 17: 784-804.

67. Minde DP, Radli M, Forneris F, Maurice MM, Rüdiger SG. Large extent of disorder in Adenomatous Polyposis Coli offers a strategy to guard Wnt signalling against point mutation. PLoS ONE 2013; 8(10): e77257

68. Hajrezaie M, Shams K, Moghadamtousi SZ, Karimian H, Hassandarvish P, Emtyazjoo $\mathrm{M}$ et al. Chemoprevention of colonic aberrant crypt foci by novel schiff based dichlorido(4- methoxy-2-\{[2-(piperazin-4-Ium-1-Yl) ethyl] iminomethyl\} phenolate) Cd complex in azoxymethane-Induced colorectal cancer in rats. Sci Rep 2015; 5: 12379.

69. Levine AJ. P53, the cellular gatekeeper for growth and division. Cell 1997; 88(3): 323-331. 